NASA Technical Memorandum 89825

\title{
Design, Development, and Test of Shuttle/ Centaur G-Prime Cryogenic Tankage Thermal Protection Systems
}

Richard H. Knoll

Lewis Research Center

Cleveland, Ohio

and

Peter N. MacNeil and James E. England

General Dynamics

Space Systems Division

San Diego, California

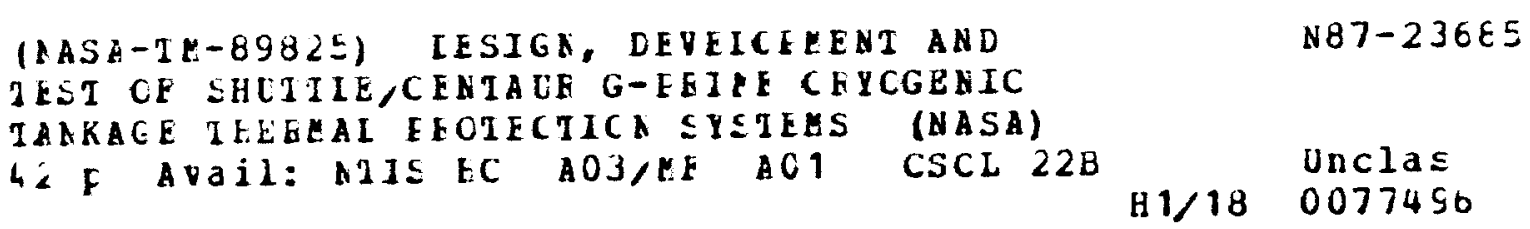

May 1987 
Trade names or manufacturers' names are used in this report for identification only. This usage does not constitute an official endorsement, either expressed or implied, by the National Aeronautics and Space Administration. 
DESIGN, DEVELOPMENT, AND TEST OF SHUTTLE/CENTAUR G-PRIME CRYOGENIC

TANKAGE THERMAL PROTECTION SYSTEMS*

\author{
Richard H. Knoll \\ National Aeronautics and Space Administration \\ Lewts Research Center \\ Cleveland, Ohto 44135 \\ and \\ Peter N. MacNeil and James E. England \\ General Dynamics \\ Space Systems Division \\ San Dlego, Californta
}

\begin{abstract}
SUMMARY
The thermal protection systems for the shuttle/Centaur would have had to provide fall-safe thermal protection during prelaunch, launch ascent, and on-orbit operations as well as during potential abort, where the shuttle and Centaur would return to Earth. The thermal protection systems selected used a helium-purged polyimide foam beneath three radiation shields for the liquidhydrogen tank and radlation shields only for the liquid-oxygen tank (three shlelds on the tank sidewall and four on the aft bulkhead). A double-walled vacuum bulkhead separated the two tanks. The liquid-hydrogen tank had one 0.75-in.-thick layer of foam on the forward bulkhead and two layers on the larger-area sidewall. Full-scale tests of the flight vehicle in a simulated shuttle cargo bay that was purged with gaseous nitrogen gave total prelaunch heating rates of $88500 \mathrm{Btu} / \mathrm{hr}$ and $44000 \mathrm{Btu} / \mathrm{hr}$ for the liquid-hydrogen and -oxygen tanks, respectively. Calorimeter tests on a representative sample of the ilquid-hydrogen-tank sidewall thermal protection system indicated that the measured unit heating rate would rapidly decrease from the prelaunch rate of $\sim 700 \mathrm{Btu} / \mathrm{hr} \mathrm{ft}{ }^{2}$ to a desired rate of $<1.3 \mathrm{Btu} / \mathrm{hr} \mathrm{ft}^{2}$ once on-orbit.
\end{abstract}

\title{
INTRODUCTION
}

The shuttle/Centaur G-prime vehicle, using liquid hydrogen and liquid oxygen as propellants, was designed for use in the Space Transportation System (STS) and afforded a means of significantly increasing the payload capability of the STS (ref. 1). Although the shuttle/Centaur project has been terminated, the design, development, and test history of the cryogenic tankage thermal protection systems used for the vehicle are reviewed to possibly benefit future programs requiring the transfer of cryogenics to Earth orbit.

The thermal protection systems for the Centaur G-prime liquid-hydrogen and-oxygen tanks were unique in that they would have had to provide thermal protection during prelaunch, launch-ascent, and on-orbit operations as well as

*A shorter version of this report was presented at the 22 nd Thermophysics Conference sponsored by the American Institute of Aeronautics and Astronautics, Honolulu, Hawa11, June 8-10, 1987 (AIAA-87-1557). 
during abort operations, where the shuttle and its cargo would return to designated landing sites. Other cryogenic stage thermal protection systems such as those for the shuttle main tank, the Saturn, and the Centaur D-1A (ref. 2) provide protection primarlly during prelaunch and aerodynamic boost. The Centaur D-1T (ref. 3), used as a second stage on the Titan, also had to provide thermal protection for an extended time on-orbit, but none of the expendable vehicles had a requirement to return to Earth. In addition to affording thermal protection during descent and landing (and after landing), it was imperative that the Centaur G-prime thermal protection systems not be hazardous to the shuttle or its crew.

This report describes (1) the basic design of the shuttle/Centaur G-prime thermal protection systems, (2) varlous small-scale and full-scale developmental tests. (3) shuttie-related developmental problems encountered and their solutions, and (4) the full-scale performance of the flight system in a simulated shuttle cargo bay during prelaunch operations. Emphas is is placed on the liquid-hydrogen-tank insulation system as it had to meet the design criteria imposed on all shuttle/Centaur thermal protection systems plus had the additional requirement, because of the lower temperature of the 11quid-hydrogen tanks, of precluding formation of liquid air or liquid nitrogen on any of its surfaces.

\section{SYSTEM DESIGN REQUIREMENTS}

Thermal Requirements for Mission

The shuttle/Centaur G-prime vehicle (ref. 1) was originally designed to propel the Galileo and Ulysses spacecraft from low-Earth orbit to their respective destinations of Jupiter and a polar orbit about the Sun (via Jupiter). The G-prime vehicle and its payloads were to be inserted into low Earth orbit by the STS. Once in orbit the orbiter cargo bay doors were to open to allow the Centaur G-prime to be rotated by its integrated support structure for eventual separation from the orbiter (fig. 1). Nominal mission time was $6 \mathrm{hr}$ from STS launch to separation from the orbiter. An additional $3 \mathrm{hr}$ was allowed for deployment delay, giving a total of $9 \mathrm{hr}$. Durling this $9 \mathrm{hr}$ the thermal environment imposed on the vehicle would vary from a room-temperature, gaseousnitrogen-purged environment at launch to the near vacuum of space, with a varying radiant heat flux once on-orbit. Additionally in case of an abort the orbiter cargo bay would have had to be refllled with atmospheric air during its descent to Earth.

Figure 2 gives additional details of the Centaur G-prime and the Centaur integrated support structure (CISS) used for interfacing with the shuttle. The vehicle is supported by a cylindrical deployment adapter on its aft end and by a three-point attachment system on its forward end. The CISS would have provided all the necessary fluid and electrical interfaces for the vehicle plus the hardware required for deployment.

The basic vehicle, before installation of the cryogenic tankage thermal protection systems and other flight hardware, is shown in figure 3 . The vehicle had the following key thermal features: (1) the highly conductive aluminum conical forward adapter (where most of the avionics and other equipment was mounted) was supported off the liquid-hydrogen tank forward ring by a lowconducting, 25-in.-high composite adapter; (2) the 1iquid-hydrogen and-oxygen 
tanks were separated by a double-walled vacuum bulkhead that contained a cryopumped insulation system to limit gaseous conduction; and (3) a low-conducting composite adapter was also used between the aft end of the liquid-oxygen tank and the warmer aluminum deployment adapter of the CISS.

In order to accomplish the intended missions, in the rather severe and varying environment discussed previously, the following thermal criteria were imposed on the cryogenic thermal protection systems:

(1) The system shall be designed to prevent liquefaction of air or the cargo bay gaseous-nitrogen purge gas on any external surface of the insulation system.

(2) The prelaunch heating rates of the liquid-hydrogen and-oxygen tanks shall be less than 103000 and $40000 \mathrm{Btu} / \mathrm{hr}$, respectively, while in the gaseous-nitrogen-purged cargo bay.

(3) The maximum on-orbit heating rates through the liquid-hydrogen-tank forward bulkhead and sidewall insulation system shall not exceed 1690 and $1570 \mathrm{Btu} / \mathrm{hr}$, respectively.

(4) The maximum on-orbit heating rates through the liquid-oxygen-tank sldewall and aft bulkhead shall not exceed 175 and $180 \mathrm{Btu} / \mathrm{hr}$, respectively.

With these requirements imposed on the cryogenic tankage thermal protection systems, along with other restrictions on penetration heat leaks and the heat leak through the double-walled vacuum bulkhead, the Centaur G-prime could perform its intended missions.

\section{Requirements Imposed by Shuttle Cargo Bay}

As a payload in the STS the Centaur G-prime had to meet the safety requirements specified in references 4 and 5 and had to withstand the STSinduced environments described in reference 6 . Some of the more important safety criterla influencing the thermal protection system design were as follows:

(1) Materials must be noncombustible or self-extinguishing in the upward flame propagation test of reference 7 (less than 6 in. burned in a 12-in.-long sample).

(2) The insulation system shall be designed to an ultimate safety factor of 1.4 or more and shall be capable of withstanding limit loads without loss of function and ultimate loads without fallure.

(3) All systems shall be two-fallure tolerant against catastrophic hazards.

(4) Any materlal exposed to gaseous or liquid oxygen must pass the impact sensitivity tests of reference 7 .

(5) All hardware with metalized surfaces shall be electrically bonded per MIL-B-5087. Cargo bay hardware with volume resistivities greater than $10^{9}$ ohms-cm shall not accumulate an electrical charge. 
The STS-induced structural loads that had to be considered in the design of the thermal protection systems were launch and emergency landing loads, mechanical loads due to structure-borne or alrborne (1.e., acoustical) excitatfons, loads due to rapid pressure changes in the cargo bay during ascent and abort descent, and localized loads on the insulation system due to flow impingement near the cargo bay vent ports.

Finally all materlals used in the cargo bay had to meet strict outgassing and cleanliness requirements.

\section{SYSTEM DESIGN}

\section{Basic Design Concept}

The basic cryogenic thermal protection systems selected for the shuttle/ Centaur G-prime vehicle are depicted in figure 4. The ilquid-hydrogen tank was insulated with a combination of helium-purged, open-cell polyimide foam and radiation shlelds; the liquid-oxygen tank used radiation shields only.

The hellum-purged insulation system on the liquid-hydrogen tank was required to prevent 1 lquefaction of the cargo bay gaseous-nitrogen purge during prelaunch and to prevent liquefaction of alr during abort operations, when the cargo bay would be refllled with alr during shuttle descent. (The gaseoushellum purge would be terminated at $11 \mathrm{ft}$-off but reinitiated if an abort occurred.) The hellum purge was contalned by the forward adapter purge diaphragm (fig. 4), the forward adapter itself, the innermost sidewall radiation shleld, which was external to the foam and acted as a sealed membrane, and the purge plenum, which sealed the system on the aft end of the liquid-hydrogen tank. The foam insulation $(1.5 \mathrm{in}$. on the tank sidewall and 0.75 in. on the forward bulkhead) was used to achleve sufficlent thermal resistance to meet the ground-hold heating criteria and to ensure that all the radiation shield temperatures exceeded the liquefaction temperatures of the surrounding gases during operation within the atmosphere. The radiation shields themselves afforded very ilttle thermal protection during ground-hold operations but would provide nearly all the thermal protection once the shields were evacuated on-orb1t. Three shlelds on both the 1lquid-hydrogen-tank forward hulkhead and sidewail were determined to be sufficient to meet mission requirements.

The llquid-oxygen tank used radiation shields only and required no purge since there was no danger of liquefying the gaseous-nitrogen purge or air on the warmer liquid-oxygen-tank surface. Because of the heat capacity and relatively small surface area of the liquid-oxygen tank. 11ttle or no thermal protection was needed for the ground-hold phase. The shields were used primarlly to afford thermal protection on-orbit. Three shields were used on the tank sidewall and four on the aft bulkhead. The inner and outer shlelds on the aft bulkhead ( $f i g .5)$ were edge vented rather than broadside vented. From the standpoint of gas evacuation on-orb1t, it would be better to have all shields broadside vented. The edge venting of the inner and outer shields was primar11y used to contain and funnel the colder gaseous nitrugen to areas where temperature-sensitive components would not be affected during prelaunch.

Figure 5 also deplcts some of the other radiation shield systems used on the aft-end components. The list is not complete but illustrates the shape, size, and varlety of shield systems required to meet the mission objectives. 
The number of shlelds used on the varlous components varied with the thermal requirements of each component, but in general the liquid-oxygen tank did not require spectal purge systems as did the liquid-hydrogen tank.

The general operation of the purge system for the liquid-hydrogen-tank thermal protection system is depicted in figure 6 . A controlled flow of helium from the Centaur integrated support structure (CISS) would enter the helfumpurged volume, discussed previously, through the forward adapter. The hellum supply system from the CISS (not shown) had two redundant flow control branches that were controlled by the three differential pressure (AP) transducers located within the forward adapter purge volume. These $\Delta P$ transducers measured the differential pressure between the enclosed volume of the forward adapter and the external environment surrounding the Centaur (i.e.., the STS cargo bay). The system was single-fallure tolerant against fallure of the $\Delta P$ control transducers and single-fallure tolerant mechanically to prevent overpressurization during an abort return. Software control via the $\Delta P$ set points allowed the purge volume differential pressure to be adjusted for various phases of prelaunch and postlaunch activities.

The helium purge would begin roughly $1 \mathrm{hr}$ before the cryogenic propellants were loaded. Prior to this time gaseous nitrogen would be maintained in the purge volume to preclude any damage to the shield surfaces from molsture condensation. At helium purge initiation the insulation blanket $\Delta P$ limits were set high enough to allow the $\Delta P$ within the purge volume to exceed that necessary to open the relief valves located in the purge plenum on the aft end of the 1lquid-hydrogen tank. These rellef valves opened at a nominal $0.4 \mathrm{psid}$. Once the valves were opened, the heavier gaseous nitrogen would be forced out by the lighter helium entering the forward bulkhead area. Figure 6 schematically shows the purge flow through one of the relief valves during the gaseous-nitrogen removal cycle. This flow and blanket $\Delta P$ would be maintained for at least $1 \mathrm{hr}$ to ensure that most of the condensable gases were purged from the system. After $1 \mathrm{hr}$ the blanket $\Delta P$ control 1 imits would be reset (via software) to maintain the nominal $\Delta P$ between 0.1 and 0.3 psid, thus closing the relief valves. At this point the hellum purge supply would be governed by the leakage rate of the insulation blanket. The liquid-oxygen and -hydrogen tanks would then be loaded ( $\sim 9 \mathrm{hr}$ before launch).

These $\Delta P$ limits would be generally maintained until fust before launch, when the limits would be lowered preparatory to venting the cargo bay at $11 \mathrm{ft}$ off. This was necessary since the cargo bay itself is slightly pressurized ( 0.5 to 0.7 psid) by its gaseous-nitrogen purge. A similar adjustment in blanket pressure would also occur earlier when the cargo bay pressure would be adjusted for hazardous gas checks. At launch a vent door (not shown) in the forward adapter would be opened, and the pressure within the contained purge volume would then closely follow that of the cargo bay during ascent. In an abort a second vent door would reseal the forward adapter, and the helium purge would be reinitiated.

\section{Design of Liquid-Hydrogen-Tank Insulation System}

As discussed previously the radiation shields on the liquid-hydrogen tank were representative of most of the shields used for the Centaur G-prime thermal protection systems. Because of the additional need to prevent liquefaction of the gases surrounding the liquid-hydrogen tank, the resulting insulation system 
was more complex and as a result was the focal point for most of the developmental testing. For this reason only the liquid-hydrogen-tank insulation system is addressed in more detall for the remainder of this report.

Material selection. - The insulation materials selected for the liquidhydrogen tank are shown in figure 7. The purge diaphragm on the forward end of the vehicle consisted of two Kevlar-cloth-reinforced shields separated by an embossed Kapton shleld. The high-strength relnforced shields were required to withstand a purge system design $\Delta P$ of 0.5 psid. These shields are actually laminates with the high-strength Kevlar cloth sandwiched between two layers of Kapton. All shield surfaces had a vapor-deposited layer of aluminum (VDA) applied to achleve emittances of 0.05 or less. The embossed Kapton was used for the middle shleld to save weight (unit weights are given in table I). Both of the outer two shlelds were broadside vented so that they could be rapldiy evacuated during ascent to eliminate most of the gaseous conduction heat transfer. The nonvented inner shield provided the required seal for the helium purge.

The insulation system for the forward bulkhead consisted of a $0.75-1 n .-$ thick layer of open-cell polyimide foam covered by three radiation shields. The outermost shield is a laminate of Nomex scrim sandwiched between two layers of Kapton. This material was selected for its low weight and rip-resistant features. The higher strength materlal used on the purge diaphragm was not required here since the forward bulkhead insulation was completely contained within the helfum-purged volume and therefore was not exposed to any differential pressures. The center shleid was embossed Kapton and the innermost shield was a flat Kapton sheet (again for weight savings), and all three shlelds had a VOA coating on all exposed surfaces. Both of the outer two shlelds were broadside vented; the inner shield was edge vented. Edge venting on the inner layer was selected to minimize the amount of hellum between the shields during ascent venting of the forward bulkhead area. The foam insulation next to the tank wall contained a typical twin-pin fastener used to attach adjacent foam panels. A layer of Tedlar tape was applled over the seam before pin installation to help minimize direct convection paths between the shields and the tank surface.

The materlals selected for the sidewall shield system consisted of two layers of polyimide foam (each $0.75-1$. - thick) covered by three radiation shields. The shields were identical to those used on the purge diaphragm except for the outermost laminate material used on the outboard shield. Instead of Kapton with an external VDA coating, a 0.5-mij-thick layer of Tefion with an internal VDA coating was used to achieve a relatively low ratio of solar absorptance to thermal emittance a/c. This low ratio was required to help minimize heating from the Sun and the Earth's albedo while on-orbit. Materlal specifications for all outboard radiation shield surfaces required that the solar absorptance be less than or equal to 0.14 and the thermal emittance be greater than or equal to 0.4 to give an $\alpha / \varepsilon$ ratio of less than 0.35 .

The structural property requirements of the sidewall shield material were primarily dictated by the radial hoop stress created by the design differential pressure of 0.5 psid used for the helium purge system. For the 87-in.-radius sidewall shield, a materlal tensile strength of $43.5 \mathrm{lb} / \mathrm{ln}$. Was required. With an ultimate factor of safety of 1.4 the shield materlal had to have a tensile strength exceeding $61 \mathrm{lb} / \mathrm{in} .(1.4 \times 43.5)$. The material specifications were conservatively established at a minimum tensile strength of $100 \mathrm{lb} / \mathrm{in}$. The 
material eventually selected - the Kevlar-reinforced shlelds - had a measured tensile strength of $239 \mathrm{lb} / \mathrm{in}$. In the undamaged state and $191 \mathrm{lb} / \mathrm{ln}$. with the material severely creased.

Finally the particular materials selected met the flammability and outgassing requirements of the shuttle cargo bay and in many cases were the same general materials used extensively in the cargo bay (e.g., aluminized Kapton).

Design deta1ls. - The general method of attachment and construction of the forward adapter purge dlaphragm is shown in figure 8 . The diaphragm was constructed from gore sectors sewn at their adjoining seams. Each gore sector contained three radiation shields. The sewn joint seam had aluminized (VDA) tape applied both outboard and inboard. The inboard tape had a thermal plastic adhesive to help ensure an adequate seal. A circular shield section was applied similarly in the center of the diaphragm to close out the shield. At the outer edges of the dlaphragm a Kevlar strip was sewn to the shields to provide a rigid edge member for attachment to the forward adapter. The method of attachment, shown in view $D$, sandwiches the Kevlar edge member between the adapter and a retalner ring bolted around the periphery of the diaphragm. A sllicone sealant was applied to the edge member and the forward adapter to ensure a proper seal. An installed dlaphragm is shown in figure 9.

Detalls of the insulation system used for the forward bulkhead area are given in figure 10. The cross section of the forward adapter shows the corrugated composite stub adapter joining the aft ring of the aluminum conical adapter to the forward ring of the 1iquid-hydrogen tank. A 12-in. strip of polyimide foam, which overlapped the tank sidewall foam, was bonded to the apexes of the corrugation to preclude locallzed chllling of the overlying radiation shield. Foam was bonded to an outside corrugation of the adapter wherever a seam was required in the 12-in. foam strip (six places). Polyimide foam was also bonded to all the inside corrugations to help reduce convective heat exchange inside the adapter from the tank surface just forward of the tank ring. The 0.75-in.-thick polyimide foam layer used on the forward bulkhead surface penetrated as far as practical into this crevice. It was held in place by the radiation shields, which were attached with velcro to the inner surface of the composite adapter. The twin-pin fasteners that hold the adjacent goreshaped foam panels together, intermittently penetrated the radiation shields to secure the two systems together. Figure 11 shows the foam panels being assembled for the full-scale test vehicle, which was representative of the flight articles. As shown, the foam seams, containing the twin-pin fasteners, were taped to minimize direct convective currents between the liquid-hydrogentank surface and the overlying shields. The hole in the foam at the top of the insulation panels was for an access door to the liquid-hydrogen tank. At final assembly a foam panel and a radiation shield cover were applied over the door.

The three-layer radiation shield system used on the forward bulkhead was laid up and attached to the underlying polyimide foam (shown in fig. 11) before it was applied to the llquid-hydrogen tank. The inner two shlelds were each fabricated by taping 16 adjacent gore sectors together on the foam-covered layup tool. The outermost, Nomex-scrim reinforced shield, was made up of four quadrant-sized pieces that were intermittentiy attached along their edges by twin-pin fasteners penetrating the entire assembly. Each quadrant was formed by sewing together four gore-shaped panels as shown in figure 12. The sewn seams used a simple stitch joint because the shield system did not have to withstand pressure forces as did the purge diaphragm. The velcro pattern near 
the center of the shield was for attachment of the forward door shield. Not shown, for clarity, are the other two shleld quadrants and the various penetrations for tank vents, instrumentation, etc. The entire insulation system on the forward bulkhead, including the foam, the shleld, the fasteners, etc., weighed $22.51 \mathrm{~b}$, or about $0.085 \mathrm{lb} / \mathrm{ft}^{2}$.

Detalls of the liquid-hydrogen-tank sidewall insulation system are shown in figure 13. As discussed previously two 0.75 -in.-thick layers of polyimide foam with three overlying radiation shields provided the necessary thermal protection for the 11quid-hydrogen-tank sidewall. Each layer of foam was composed of several panels, each containing a cylindrical sector and a conical sector and running from the forward tank ring to the aft end of the conical section of the 1lquid-hydrogen tank. The cylindrical and conical sectors were bonded where they met. The seams between adjacent panels (running fore and aft) of the inner layer were offset from those of the outer layer to mimimize direct convective currents between the tank surface and the overlying shields. The foam panels were held at the fore and aft ends by support channels attached to the forward tank ring and by channels attached to tank brackets at the aft end of the tank's conical portion. The foam panels had Kevlar channels bonded to their edges fore and aft to reinforce the support pins that held the panels within the brackets. Figure 14 shows the installation of one of the inner panels at the forward tank ring. Also shown is a twin-pin fastener penetrating the side of the panel. which again had bonded Kevlar strips to reinforce the foam pane1. The aft brackets for foam panel attachment are shown in figure 15 along with the purge plenum, which transitioned the vacuum bulkhead between the 11quid-oxygen and-hydrogen tanks. The aft end of the plenum was bolted to and sealed to a continuous circumferential ring on the forward end of the liquidoxygen tank. (Also shown is one of the two purge rellef valves discussed previousiy in the section "Basic Design Concept.") The entire inner surface of the plenum was lined with a $0.75-i n$.-thick layer of polyimide foam to maintain temperatures well above the condensation temperature of air or gaseous nitrogen.

Most major penetrations of the liquid-hydrogen-tank insulation system were made in one locallized area (designated "the cableway") to minimize sealing problems for the hellum purge system. The aft end of this area is shown in figure 16. All the required wire harnesses and fluid lines extended forward up the side of the liquid-hydrogen tank to the forward adapter. Foam insulation was installed both beneath and above these harnesses and fluid lines in the cableway area (outer layer is not shown). The brackets for attaching the sidewall foam panels are shown on both sides of the cableway. Once the sidewall foam panels were attached to these brackets, a strip of Tedlar tape was applied along the whole length of both seams to minimize convective flow from these direct butt joints. The engine feed line and tank flll/drain line, shown exposed, had insulated shroud enclosures that were sealed and purged with hellum during prelaunch operations. Before these shrouds were installed, Tedlar tape was used to seal off all direct butt joints with the adjoining foam panels. An additional insulated-purged shroud also was installed over the lower end of the cableway with its uppermost surface running laterally between the two liquid-hydrogen line shrouds.

Detalls of the 11quid-hydrogen-tank sidewall radiation shield construction are given in figure 17. The shleld was assembled from 3 circumferential panels and 13 conical sectors. The maximum size of the panels was dictated by the avallable stock width of the radiation shield materials. Each panel contained 
three radiation shields, as described previously, with the nonvented sealing shleld located inboard. The radlation shlelds for each panel were temporarily held in place with aluminized Kapton tape before they were sewn for the final assembiy. A typical sewn joint used to join adjacent panels is shown in view A-A. Two stitches are used to secure the joint and then a VDA-coated tape with a thermal plastic adhesive was applied to the inner surface, and a VDAbacked Tefion tape was applied to the outer surface. The tape used externally was selected because it approximately matched the a/c ratio of the outer shield surface. A typical shield edge for mechanically attaching the shield to the vehicle is shown in view $C-C$. The shield was sewn to the thinner section of a reinforcing Kevlar strip and then taped as discussed previously. The thicker portion of the reinforcing strip was sandwiched between the desired sealing surface and a retaining ring held with bolts and sealed nutplates as shown in figure 13 (for attachment to the purge plenum). A sealant was used on the inboard surface of the reinforcing strip to complete the seal. The radiation shield system was sealed similarly at its forward end to the aluminum adapter ring (e.g., see fig. 10) and laterally along the port side of the area containing the fluid lines and electrical harnesses. Areas around the line penetrations, etc., were treated similarly. The completed sidewall insulation system (including the shlelds, the foam layers, the fasteners, the retainer rings, etc.) weighed $119.21 \mathrm{~b}$, or about $0.251 \mathrm{~b} / \mathrm{ft}^{2}$.

The completed insulation system for the vehicle is shown in figure 18 . There were many other insulated components on the vehicle, and they in general used three or four shields with the same materials and assembly techniques (1.e., sewn seams). Exceptions were as follows: (1) the liquid-oxygen sump contained 16 shield layers, and (2) the liquid-hydrogen fill/drain line, aft of the purged elbow at the tank, used a sealed foam under non-hellum-purged radiation shields.

Finally the techniques used to electrically ground all the metalized (VDA) shield surfaces on the vehicle are shown in figures 19 and 20 . The VDA surfaces of the radiation shields were grounded to the vehicle by using the techniques shown in figure 19. Specifications for assembling the shield system required that the resistance between any vehicle ground and any vehicle radiation shield be less than 100 ohms. The resistance across the ground wire attachment itself had to be less than 1 ohm.

As mentfoned previously the outermost shields on the vehicle had a 0.5-mil-thick Tefion coating covering a VDA coating within the shield laminate. Because of the large surface area of the sidewall shlelds there was concern that this "hidden" VDA surface could act as one plate of a large capacitor if sufficlent charge were to accumulate from whatever source. Although a charging mechanism was not present for the anticipated missions, the hidden VDA was grounded as a precautionary measure. The method finaliy selected for grounding the hidden VDA is shown in figure 20. A conductive ink was applied on all external shield edge surfaces. This served to electrically connect the hidden VDA with the exposed VDA on the underside of the shield (which was grounded to the vehicle by the techniques shown in $\mathrm{fig}$. 19). Test tabs were also included on major shield surfaces to verify that the hidden VDA was grounded and to help monttor any degradation with time. Requirements specified that the resistance between the exposed VDA surface (grounded to the vehicie) and the hidden VDA surface be less than 50000 ohms. This was more than adequate to preclude any electrostatic discharge since it provided a leakage path for any accumulated charges. 
Predicted performance. - The predicted steady-state heat transfer rates into the insulated Tiquid-hydrogen tank are given in table II for prelaunch ground hold and for a representative on-orbit case for the Gallieo $\mathrm{mission}$. It is apparent that the forward bulkhead and sidewall are the predominant heat transfer contributors during ground hold, whereas the common vacuum bulkhead would be the major contributor once on-orbit. The surface areas of these major contributors are as follows: forward bulkhead $216 \mathrm{ft}^{2}$; sidewall, $483 \mathrm{ft}^{2}$; and intermedlate bulkhead, $129 \mathrm{ft}^{2}$.

The predicted translent performance of the forward bulkhead and sidewall insulation systems is shown in figure 21 . Shortly after launch the expected heating rates drop by roughly a factor of 100 once the pressures within the insulation approach near-vacuum conditions. The radiation shield temperatures and heating rates then rise until the cargo bay doors are opened at $1 \mathrm{hr}$ after launch. At this point the temperatures generally decrease in a cyclic fashion (due to day-night cycles) as steady-state conditions are approached. These predicted temperatures and heating rates are compared with those achleved during developmental testing in subsequent sections of the report.

\section{DEVELOPMENTAL TESTING}

In developing the Centaur G-prime thermal protection systems, many tests, varying from simple bench tests to full-scale system hardware tests, were performed. For convenience of discusston these tests are grouped into the following general categories (not necessarily in chronological order): (1) smallscale material tests: (2) calorimeter tests; (3) tests related to shuttle cargo bay safety requirements; (4) full-scale liquid-hydrogen-tank insulation system tests; and (5) flight vehicle ground-hold tests.

\section{Small-Scale Material Tests}

Polyimide foam tests. - The polyimide foam used for the liquid-hydrogen tank was an open-cell foam with a density of $0.60 \mathrm{lb} / \mathrm{ft}^{3}$. The tests performed on the foam and the test results are summarized as follows:

(1) Mechanical properties: The measured average ultimate tensile strength and modulus of elasticity at $-320^{\circ} \mathrm{F}$ were 17.6 and $140 \mathrm{ps} 1$, respectively.

(2) Thermal properties: The measured coefficlent of thermal expansion was $4.4 \times 10^{-5} \mathrm{in.} / 1 \mathrm{n}$. ${ }^{\circ} \mathrm{F}$ between -121 and $3^{\circ} \mathrm{F}$.

(3) Air purgeout: The time required to reduce the air concentration to 10 percent with a helium purge from top to bottom along the longest dimension was $8.3 \mathrm{~min}$ for a sample 1 by 10.75 by $46.5 \mathrm{in}$.

(4) Particle generation during rapid depressurization: An insignificant number of particles were given off, and no cell breakage was detected after the open-cell polyimide foam was subjected to a launch-ascent pressure proftle.

The actual surface area of the forward bulkhead is $266 \mathrm{ft}^{2}$. For conventence of thermal modeling a portion of this area was accounted for in the forward adapter calculation. 
(5) Heat forming: The heat-forming cycle for the curvatures required for the Centaur G-prime tank was determined to be $15 \mathrm{~min}$ at $500^{\circ} \mathrm{F}$.

(6) Insulation compression due to rapld chilling of hellum during liquidhydrogen tanking: A 4.0-in.-diameter, 1.0-in.-thick cylindrical foam specimen was tested for compression and recovery at temperatures experlenced during tanking. The equilibrated surface temperatures were $-360^{\circ} \mathrm{F}$ for the bottom and $-150^{\circ} \mathrm{F}$ for the top. The compression was $0.37 \mathrm{in.}$, and the recovery was 100 percent in approximately 2 min.

In general the foam tested was ideal for the application intended and met all mission requirements.

Shteld materlal tests. - The structural tests performed on the reinforced radiation shield materials and the sewn seams are summarized in table III. The fiberglass-cloth-based materlal was originally selected and used in the fullscale insulation tests discussed later in this report. The creased-strength data were acquired after several small creases were noticed as the shleld was being assembled for the full-scale test vehicle. These data and results of the full-scale insulation system tests eventually led to changing the liquidhydrogen-tank sidewall shield material to the Kevlar-based material, which has superior strength even in the creased state. As shown, the strength of the sewn seam joint samples also exceeded the 43.5-1b/in. design requirement.

The radiative surface properties of the shield materials were also determined, and representative results are given in table IV. The fiberglass data are for a fiberglass cloth that was strategically located on components exposed to exhaust plume heating from the vehicle's reaction control system. The materials used met all the requirements.

\section{Calorimeter Tests}

A series of tests were performed on a 9.5-in.-diameter double-guarded calorimeter to determine the performance of the 1lquid-hydrogen-tank insulation system during simulated prelaunch, launch-ascent, and on-orbit conditions.

Figures 22 and 23 give the steady-state thermal performance of the liquidhydrogen-tank insulation system for various radiation shield (test chamber) pressures. 1 Pressures within the foam, near the tank surface, were also recorded and were roughly 10 times higher than the chamber pressure. The test configuration shown (1.e., with two polyimide foam layers) was actually an earlier version of the forward bulkhead insulation, and the tests were primarily designed to simulate the hellum-purged forward adapter area of the vehicle. The data, however, should be representative (1) of the single-layer foam configuration (selected for the forward bulkhead) for the lower pressures, where the foam contributes 11 tt le thermal resistance, and (2) the tank sidewall insulation, provided the volume beneath the inner shield evacuates reasonably well.

IData from an internal GDSSD report by A. Burgelis. A 1 imited amount of the data is reported in reference 8 . 
The temperature data in figure 22 are quite consistent and generally show the expected effects of decreasing pressure. That is, the foam temperatures decreased rapldiy, and the radiation shlelds began to approach a fourth power temperature profile. Most of the data were taken with the thermocouples accidentally unshielded (1.e., the high emissivity epoxy cement used to secure the thermocouples to the shieid was left exposed and localiy affected the shield temperatures but had no effect on heat transfer). One set of data, however, at a pressure of $2 \times 10^{-4}$ torr, were taken with the thermocouples properly covered with aluminized tape, and this set varied significantly from the other data. The temperatures acted as expected and in fact approached those of the predicted results for pure radiation heat transfer shown on the left side of the figure.

The heat transfer data shown in figure 23 indicate that, for the lower pressures expected on-orbit (1.e., 10-4 torr or less), heat transfer rates on the order of 1 Btu/hr $\mathrm{ft}^{2}$ wtil be achlevable with external shield temperatures of $465^{\circ} \mathrm{R}$. The predicted data given in figure 21 show the lowest heating rates and corresponding outer shield temperatures to be about $1.14 \mathrm{Btu} / \mathrm{hr} \mathrm{ft}^{2}$ and $400^{\circ} \mathrm{R}$ for the stdewall and $0.85 \mathrm{Btu} / \mathrm{hr} \mathrm{ft}^{2}$ and $335^{\circ} \mathrm{R}$ for the forward bulkhead. Its obvlous that if the experimental data were scaled to the outer shleid temperatures expected on-orbit, the heating rates would be even lower than required to accomplish the mission.

One of the concerns was how rapldly the forward bulkhead foam would evacuate in order to quickly achleve the desired lower heat transfer rates on-orbit. Figure 24 indicates that most of the helium gas would be vented quite rapidiy. After $5 \mathrm{~min}$ the heat transfer rate has dropped to less than $5 \mathrm{Btu} / \mathrm{hr} \mathrm{ft}^{2}$. The slower dropoff after $5 \mathrm{~min}$ was due to a hydrogen leak in the calorimeter. Additional tests were planned to repeat these tests but were abandoned when the shuttle/Centaur program was terminated. It is expected though that heat transfer rates on the order of $1 \mathrm{Btu} / \mathrm{hr} \mathrm{ft}^{2}$ would be achlevable within $15 \mathrm{~min}$ after launch.

\section{Tests Related to Shuttle Cargo Bay Safety Requirements}

Electrostatic discharge. - One of the requirements for the shuttle cargo bay hardware was that any surface exceeding a volume resistivity of $10^{9}$ ohms $-\mathrm{cm}$ be designed to prevent the accumulation of an electrostatic charge. Because the volume resistivity of the Tefion film on all outboard radiation shields exceeded $1015 \mathrm{ohms}-\mathrm{cm}$, some means of preventing a charge accumulation had to be provided or, with proper safety verification, a waiver could be obtained. As mentioned earlier, the hidden VDA beneath the Tefion surface was grounded with a conductive ink applied at the shield edges. This grounding technique was selected after trying several mechanical methods of grounding such as rivets, serrated washers, and stainless steel thread. Most of the mechanical methods achleved a good ground initlally, but the ground disappeared after a short time probabiy from galvanic corrosion with the thin VDA layer or from mechanical breakdown of the contact with material flexing. Figure 25 shows the effect of time on the grounding capability of conductive ink for 60 samples each of the Kevlar-reinforced shields on the liquidhydrogen-tank stdewall and the Nomex-scrim-reinforced shields used on the liquld-oxygen tank. Because some degradation takes place with time, test tabs were designed into the radiation shleld system to check the electrical grounding before flight. Many areas existed on the shields (e.g., vent holes in 
outer shleld) for reapplying the conductive ink in the unlikely possibility that all grounding disappeared.

With the metalized surfaces properly grounded the problem of volume resistivity of the Teflon f $11 \mathrm{~m}$ still had to be addressed. Two approaches were considered. The first was to consider alternative materials that had lower resistivity, and the second was to examine grounding techniques like that used on the cargo bay liner, where a 6-in.-square grid of grounding wire was interwoven into the beta-cloth liner. In selecting an alternative material both the high strength properties of the sidewall shield material and the desirable optical properties of the VDA-backed Teflon $\mathrm{f} 11 \mathrm{~m}$ had to be retained. One possible solution was to add a thin coat of indium tin oxide (ITO) to the Tefion to lower the resistivity at the surface. Discussions with other spacecraft designers and evaluation of material samples revealed that the ITO coating was very brittle and that microscopic cracks in the surface severely degraded its conductive qualities. Because of the extreme flexing of the shields during fabrication, handling, and use on the vehicle, we felt that the ITO coating would be rendered useless and this approach was abandoned.

The use of grounding wires attached to the outer shield surface was also briefly investigated. Experimental measurements of the surface charge on the outer shield material near a grounded wire revealed that the surface charge dropped to near zero at the wire but assumed the full charge fractions of an inch away from the grounding wire. Thus to achleve the desired result, an inordinately large number of grounding wires would be required.

Since netther approach was adequate for achieving the destred low surface resistivity and other methods were not evident, we decided to evaluate the consequences of accumulating a static charge. A series of tests were set up whereby a sample of the shield material was purposely charged to the highest induced potential that was practically possible and then purposely discharged. The charge lost during the discharge was measured. The energy in the arc was then calculated by conservatively assuming that both the maximum measured induced potential and the maximum measured charge lost were doubled once and then again, as an additional factor of safety. This yielded an arc energy of $0.0017 \mathrm{~mJ}$ (a factor of $16 \mathrm{higher}$ than that using the measured data). From the data of reference 9 the minimum energy required to sustain a reaction (ignition energy) for the most explosive mixture of hydrogen and air possible is 0.017 to $0.018 \mathrm{~mJ}$. This is 10 times higher than the conservatively calculated arc energy based on experimental measurements.

In addition, if the volume concentration of hydrogen in air varies from the optimum, the required ignition energy can increase dramatically. This fact along with the following was used in achieving a walver of the resistivity requirement for the outboard shields of the Centaur G-prime:

(1) There is no known charging mechanism during prelaunch, ascent, and abort descent.

(2) All metalized surfaces were grounded, including the hidden VDA.

(3) Any inadvertently applied charge (e.g., rubbing against surface by personnel) would bleed off well before the tanks were loaded with cryogenics. 
(4) Bullt-in clearance between the radiation shields and the cargo bay precluded inadvertent contact with a grounded surface.

Flow impingement from cargo bay vents. - One of the concerns that arose in integrating the Centaur into the shuttle cargo bay was the effect of highvelocity flow near the open cargo bay vents during shuttle ascent and descent. Because of the large dlameter of the Centaur G-prime, the 11quid-hydrogen-tank sidewall insulation system was relatively close to two of these open vents, and there was concern that the high-velocity flow could cause flutter or damage to the overlying radiation shields. Since it was not possible to predict the flutter - or flow-induced osclilatory stresses, a test was set up to determine the shields' responses to these conditions.

A preliminary worst-case assessment of the alrflows, by the sTs prime contractor, gave estimates of the velocity and dynamic pressure $q$ for various flight events at the two open vents exposed directly to the sidewall insulation system. The worst-case events are summarized in table $v$ along with the experimental airflows (at sea level) used to simulate these events. For the ascent condition, where the shield would be unpressurized, the maximum test airflow velocity was selected to be the same as the maximum predicted in filght. The corresponding $q$ was $52 \mathrm{lb} / \mathrm{ft}^{2}$, or 1.58 times the predicted $33 \mathrm{lb} / \mathrm{ft}^{2}$ during filight. The descent events with the shield pressurized would generally be more severe in terms of velocity and dynamic pressure. The test condition selected applied a safety factor of 1.4 to the event with the maximum dynamic pressure $\left(130 \mathrm{lb} / \mathrm{ft}^{2}\right)$, yielding a test $q$ of $182 \mathrm{lb} / \mathrm{ft}^{2}$. Although the test velocity was only $391 \mathrm{ft} / \mathrm{sec}$, it exceeded the estimated velocity of $209 \mathrm{ft} / \mathrm{sec}$ required to match the Reynolds number of the flight event. The flight event that could not be matched was the high velocity inflow at the higher altitudes (1.e., $1420 \mathrm{ft} / \mathrm{sec}$ at $72500 \mathrm{ft}$ ). This event is not considered critical, however, because of the relatively low dynamic pressure. In addition, later detalled estimates indicated that the velocity at this altitude would be closer to $840 \mathrm{ft} / \mathrm{sec}$, which further lowers the dynamic pressure to about $14 \mathrm{lb} / \mathrm{ft}^{2}$.

The experimental test setup and flow profiles imposed on a sample shield to simulate the events discussed are shown in figure 26 . The shield sample, the simulated vent area, and the distance between the vent and the shleld surface were to the same scale as the flight hardware. The foam beneath the shield also contalned a row of twin-pin fasteners (not shown) near the flow impingement area to magnify any deleterious abrasion effects in case flutter occurred. The test flow rates shown were slowly ramped to the maximum test dynamic pressures to determine if there were any oscillatory phenomena that only occurred at the lower flow rates. With the shield unpressurtzed some 1 imited movement was observed, but the movement was not organized and was of very small amplitude. During testing of the pressurized shield very little movement was noted. There was no damage to the radiation shield or the foam beneath the shteld (fig. 27).

Early in the test program a flow control valve accidently malfunctioned and exposed an unpressurized shield to a dynamic pressure of at least $1800 \mathrm{lb} / \mathrm{ft}^{2}$. The shields and foam expertenced some damage, but because it was very localized, the shteld system could still contain a hellum purge. The middle shleld, which was the lightweight embossed Kapton materlal, partially shredded near the flow impact area. We belleve that the high-pressure alr entered through the vent holes in the outer shield 10.25 -in.-diameter holes on 
4-in. centers) and caused the thinner $(0.3 \mathrm{~m} 11)$ Kapton material to shred locally. Although these conditions would never occur during flight, we decided as a precautionary measure to tape over the shield vent holes near the cargo bay vents to prevent any possible degradation due to flow impingement.

Liquid air formation. - During an abort of the shuttle after 1ift-off the 11quid-hydrogen-tank insulation system helium purge would have to be reinitiated for an eventual descent and landing. Although the Centaur propellant tanks would be emptied in the event of an abort, some residual propellants would remain in the cold-soaked tanks. If for some reason the helfum purge was unexpectedly terminated or was not reinitiated, air could be ingested into the sidewall insulation system and eventually condense on the cold ilquid-hydrogentank surface. One of the concerns for this fallure scenarlo was that liquid air (1) could posstbly compromise the structural integrity of the radiation shleids or (2) could form on the external surfaces of the sidewall radiation shields and present a potential hazard to the shuttle and its crew. Conservative estimates indicate that roughly 40 ib of 1 lquid air could be generated in vaporizing the remaining residual liquid hydrogen and warming the tank above the condensation temperature of air. If it was further assumed that all the liquid would collect on the inner shleld (vehicle in horizontal position), the inner shield temperature could drop low enough to condense the surrounding external air.

As a result of these concerns a small-scale experiment was set up to demonstrate the liquid-air containment capabilities of the sidewall radiation shields. The overall experimental setup is shown in figure 28 . A sample of the three-layer sidewall shield was used to form the major surface of a dishshaped contalner that was then fllled with liquid nitrogen. A typical sewn seam ran longitudinally along the bottom of the dish and was instrumented with thermocouples on the underside (not shown) to help determine if liquid-alr temperatures were approached. Liquid nitrogen was used because it represented the coldest temperature achievable with liquid air condensing inside the radiation shield system. The dish held approximately 110 lb of liquid nitrogen when fllled. The resulting temperature proflle across the shield seam is shown in figure 29. It is apparent that all the temperatures are relatively high, probably as a result of water frost bulldup between the shield layers. There was no evidence of structural degradation of the shield seam and no evidence of liquid runoff during the entire test. After the primary testing was completed, a small propane torch was passed back and forth below the shields $(\sim 10$ in.) to detect any liquid air or concentrations of gaseous oxygen that were not detectable from the visual observations. There were none.

On the basis of the tests conducted and the sidewall shield design used, we concluded (1) that any air ingested and subsequently liquefied within the llquid-hydrogen-tank insulation system would be contained by the inner (sealed membrane) radiation shield; and (2) that there would be rio external formation of liquid air on the radiation shield system.

Impact sensitivity of materials in liquid air/gaseous oxygen. - Because there was a potential of forming liquid air within the liquid-hydrogen-tank insulation system after single-point fallures causing loss or depletion of the helium purge during an abort. it became necessary to prove (1) that the insulation system was not impact sensitive in a liquid-air or a gaseous-oxygen environment or (2) that the probab1lity of catastrophic fallure due to impact was 
extremely low. Tests to accomplish this were under way when the shuttlef Centaur G-prime program was terminated. Partial results from one series of tests are summarlzed in table VI. The objective of these tests was to determine the impact sensitivity of the insulation materials in gaseous oxygen. The reason for this was that if any impact on the vehicle occurred, there would be a considerably higher probability of the insulation behind the impact area being flooded with gaseous oxygen rather than the liquid air, which would be in a small puddle. As seen from table VI the test results were mixed. A material has to be capable of sustaining 20 successive impacts at $72 \mathrm{ft}-1 \mathrm{~b}$ without a reaction before it is considered not to be impact sensitive. The inner shield materlal, which is the only shield exposed to gaseous oxygen, passed the test. The three-layer sidewall shleld with a typical taped seam and the polyimide foam, however, could only pass at the lower energy levels. The pressures used in the tests were considerably higher than desired because of the limitations of the standard test equipment. Plans were under way to modify the equipment for gaseous oxygen tests at 1 atmosphere but could not be completed. From the $11 \mathrm{mited}$ data taken at 50 psia, it appeared that there was a good possiblilty that the materials would have passed the impact testing at pressures near amblent. For example, the polyimide foam, which could not pass the impact tests in gaseous oxygen at 50 psia, did pass the liquid-oxygen impact tests that were done at a pressure of 1 atmosphere.

It should be noted, however, that the polyimide foam was the only element of the sidewall insulation system that passed the standard ambient liquidoxygen impact test of reference 7. This particular test completely immerses a small wafer of the candidate material in a stainless steel cup filled with liquid oxygen and then impacts it with a stainless steel anvil. In the fallure scenarios discussed prevlously, only the materials inboard of the innermost sidewall radiation shield are exposed to liquid alr. Also any impact would be cushioned by the $1.5 \mathrm{in}$. of foam (which passed the liquid-oxygen impact testing) that separates the shlelds from the liquid-hydrogen tank. For these reasons an experiment was devised to determine the impact sensitivity of the full insulation system configuration with liquid air contained within the innermost shield only. A sketch of the test setup is shown in figure 30 . This test was also in progress when the shuttle/Centaur program was canceled.

Both the partially completed impact testing discussed above and tests on the external formation of liquid alr (previous section) were an attempt to realistically assess the potential hazards involved with ingesting air into the liquid-hydrogen-tank insulation system after a single-point fallure causing loss of hellum purge. The assumptions used in estimating the amount of liquid air that would form and remain as a liquid were very conservative but justifiably so when the safety of the shuttle and its crew were involved. Depending upon the results of the uncompleted impact testing the insulation system may have demonstrated a benignity to impact and hence met the two-fallure tolerancy requirement. If not, steps would have been taken to add another level of redundancy to events causing loss of helium purge.

\section{Full-Scale Insulation System Tests}

A full-scale test of the liquid-hydrogen-tank insulation system was conducted: (1) to determine the performance characteristics of the helium purge system, (2) to determine the thermal characteristics and performance of the 
Insulation system, and (3) to evaluate the structural integrity of the insulation system. The test vehicle consisted of the Centaur G-prime propellant tanks, the forward and aft composite adapters, and the forward adapter with the purge diaphragm. Figure 31 shows the vehicle before it was installed in the test tower and before the 11quid-hydrogen-tank sidewall insulation system was installed. Once in the test tower the vehicle was enclosed in a shroud that was subsequentiy purged with gaseous nitrogen during testing to simulate the shuttle cargo bay during prelaunch. Liquid nitrogen rather than liquid oxygen was used in the uninsulated liquid-oxygen tank for safety reasons.

The insulation system on the liquid-hydrogen tank consisted of the flight design with some minor variations to accommodate the vartous full-scale vehicle tests planned. Also as mentioned earlier the radiation shield material orlginally selected and used for these tests was the fiberglass-cloth-reinforced shield material whose strength properties are given in table III.

Purge system tests. - The results of key tests on the blanket purge system are given in figures 32 and 33 . The measured helium leakage rate of the insulation blanket system (fig. 32) was well within the target leakage and showed no significant hysteresis effects. The results of two gaseous nitrogen displacement tests ( $\mathrm{fig}$. 33) show the gaseous nitrogen concentration as a function of time for two different gaseous helium flow rates. The higher rate was selected and used for the Centaur G-prime insulation system. As mentioned in the discussion of figure 6 the gaseous-nitrogen removal cycle is initiated by pressurizing the blanket with helium until the two rellef valves open to allow a flow path for removing the heavier gaseous nitrogen. It is apparent that the hour allowed for this cycle is sufficlent for removing most of the gaseous nitrogen from the system. The two rellef valves, which were designed to open between 0.35 and $0.45 \mathrm{psid}$, opened at 0.403 and $0.405 \mathrm{psid}$, respectively.

The control system for supplying the helium to the blanket performed flawlessly. Typical pressure histories for the blanket purge system are given subsequentiy in the section "Flight Vehicle Ground-Hold Testing."

Thermal performance tests. - A summary of the thermal data taken on the insulated liquid-hydrogen tank during simulated prelaunch conditions is shown in figure 34. The outer and inner radiation shleld temperatures and outer foam surface temperature data are shown as a function of the liquid-hydrogen-tank vertical and radial positions. Also included for reference is the predicted temperature of the inner and outer shields. The agreement between predicted and measured shleld temperatures was quite good except for the aft (contcal) end of the liquld-hydrogen tank. The measured temperatures on the aft end of the conical shield are markedly lower than expected. Although the temperatures were not low enough to cause liquid-nitrogen runoff, they were low enough to form water frost from the small amount of residual molsture left in the gaseous-nitrogen purge (dewpoint of $-30^{\circ} \mathrm{F}$ ). After careful post-test inspection, we concluded that the seams in the foam, where butt joints of the inner and outer foam layers colncided, were allowing the cold helium next to the liquid-hydrogen-tank wall to flow directly out to the inner shield, causing localized chlliling. All of these overlying butt joints were concentrated in the cableway area, where the electrical wires and flutd lines ran up the sidewall ( $20^{\circ}$ position) and around the major tank penetrations such as the fill/ drain line and the engine feed line elbows (e.g., see fig. 16). The measured shield temperatures were correspondingly lowest in this regton (1.e., at the $45^{\circ}$ and $135^{\circ}$ positions). As a result of these tests the design was changed to 
Include local taping of the butt joints around the areas discussed. Subsequent testing of the full-scale flight vehicle confirmed that no localized chlling occurred.

The measured heat transfer rate of $82700 \mathrm{Btu} / \mathrm{hr}$ into the liquid-hydrogen tank was well within the maximum and minimum rates of 76857 and $86935 \mathrm{Btu} / \mathrm{hr}$ predicted for the test article. These rates differed silghtly from those of table II because of the varlous peculiarities associated with the test (e.g., using liquid nitrogen rather than liquid oxygen in the 11quid-oxygen tank and different tank penetrations on the forward end). Overall, the thermal performance of the system was as expected.

structural tests. - At the conclusion of the purge and thermal performance testing several structural tests were performed on the hellum containment shield (innermost shleld). The first test consisted of a rapid pressurization to simulate the maximum rate of pressure change expected on the insulation system during shuttle ascent - about $0.3 \mathrm{psid} / \mathrm{sec}$. The second test attempted to impose a proof pressure of 0.5 psid on the system, and the final test pressurlized the shield until it falled (burst test). Prior to these tests extensive crazing or localized creasing of the outer shield material was evident (also expected on the inner containment shield), and four small tears in the outer shleld occurred as a result of the nitrogen purge gas removal tests. Despite these tears the blanket leakage remalned unchanged, indicating no faliure in the inner containment shield. These tears were repaired before the subsequent structural tests were performed. The shield system withstood the rapid pressurization tests with no change in blanket leakage although another small tear appeared. In the proof pressure test a pressure of 0.57 psid rather than $0.5 \mathrm{psid}$ was applied because of an instrumentation problem. Several additional tears in the outer shield appeared and the blanket leakage increased. In the subsequent burst test the blanket falled at 0.66 psid, well above the design proof pressure.

As mentioned previously the shield material selected for the flight vehicle was the stronger Kevlar-cloth-reinforced material. The actual decision to change materials occurred before the structural tests when extensive creasing appeared after the fiberglass-reinforced shields had been installed for the full-scale vehicle tests. The results of the structural tests further reinforced this decision.

\section{Flight Vehicle Ground-Hold Tests}

The first fight vehicle and its cISS were mounted in a simulated cargo bay at Cape Kennedy for a terminal countdown demonstration (TCD). In this test the vehicle was tanked and controlled by its onboard computer systems up to a simulated abort just priar to lift-off. Two TCD's were performed. The thermal performance of the insulated propellant tanks for the second TCD is summarized in figure 35 (results similar to that of the first TCD). The steady-state temperatures of the insulation system are shown for the various filght temperature transducers used on the vehicle. For reference the temperature data acquired on the full-scale developmental tests (previous section) are included where the sensors are in the same general location. In the forward bulkhead area the lower temperatures measured for the flight vehicle were expected since the shields on the developmental test vehicle were more locsely fitting. The original design of the developmental vehicle had two layers of foam on the forward 
bulkhead but was ultimately tested with one layer, hence causing the looseness in the shields.

The sidewall temperatures on the flight vehicle were higher, and the spread between the inner and outer shields was also higher, indicating more heat was supplied (from the surrounding walls) to the outer shield. This was expected since the emittance of the simulated cargo bay used for the TCD was considerably higher than that used for the developmental testing, where costs were kept low by using a bare oxidized aluminum material for the shroud sidewalis. The simulated cargo bay emittance was 0.85 , whereas the simplified shroud used for the developmental testing had an estimated emittance of about 0.15 . We estimated that this would cause a roughly 10 to 15 percent increase in the sidewall heating for the TCD test, and this was reflected in the test results.

Note also that the temperatures on the confcal portion of the filght sidewall shield were considerably higher and more uniform radially than those experienced on the developmental test article (fig. 34), indicating that the localized chiliting experfenced previously did not occur.

The steady-state heat transfer rates for the liquid-hydrogen and -oxygen tanks as determined from bolloff tests were 88500 and $44000 \mathrm{Btu} / \mathrm{hr}$, respectively.

The 1lquid-hydrogen-tank insulation blanket purge system performed flawlessiy throughout the simulated prelaunch countdown. Figure 36 shows a typical pressure history of the blanket demonstrating the cycling of the blanket at $5 \mathrm{~min}$ before the planned launch. Prior to $T-5$ min the blanket was in its nominal cycle mode. At $T-5$ min the control band was changed via software to prepare for the events at $11 \mathrm{ft}$-off. The control band was tightened so that the peak differential pressure was low enough to ensure that the blanket $\Delta P$ would not exceed 0.35 psid when the cargo bay vents were opened at $T-41 \mathrm{sec}$. The average $\Delta P$ of the blanket was also raised in preparation for terminating the purge at $T-20 \mathrm{sec}$. This blanket differential pressure ensures that the $\Delta P$ would still be positive at lift-off and prevents any backfilling with air. It is apparent from figure 36 that the overall cyclic performance of the blanket was smooth and well behaved.

Post-test inspection of the insulation systems after the two TCD's ind 1cated that no structural damage occurred. There was no evidence of tears in the 11quid-hydrogen-tank shields as experienced in the developmental tests and no evidence of shield creasing.

\section{CONCLUDING REMARKS}

Overal1, the Centaur G-prime cryogenic thermal protection systems, as designed and modified subsequent to the full-scale development tests, met a 11 structural and thermal requirements for the intended G-prime missions. The liquld-hydrogen-tank thermal protection system was the focus of most of the developmental efforts because its design had the additional requirement of precluding the formation of liquid nitrogen or air on any of its surfaces to prevent potential hazardous situations in the shuttle cargo bay. 
The hellum-purged foam and radiation shield blanket concept for the 1lquid-hydrogen tank proved to be lightweight, rugged, and rellable. The highstrength Kevlar-cloth-reinforced shields were more than adequate for withstanding all the pressure loads imposed on the system during prelaunch, launch, and ascent (including flow impingement through cargo bay vents) and during abort. The measured thermal performance of the liquid-hydrogen-tank insulation system during simulated prelaunch conditions was essentially as predicted, and limited calorimeter data indicated that the thermal performance on-orbit would have been adequate for the intended missions. The hellum purge system for maintaining a hellum environment around the liquid-hydrogen tank during all operations within the atmosphere performed flawlessly.

A considerable amount of development effort was necessarliy devoted to safety issues. The basic thermal protection system materials had to, and did, meet strict cargo bay flammabllity, cleanliness, and outgassing requirements. The basic system design exceeded the structural design requirements for cargo bay payloads. In fact, the inttial design, using the degraded fiberglasscloth-reinforced shields, nearly met all structural requirements. The much stronger Kevlar-cloth-reinforced shlelds that were finally selected clearly exceeded the requirements and showed no structural degradation after extensive testing during the terminal countdown demonstrations. The requirement to properly ground (electrically) all metallzed surfaces was met. Grounding of the "hidden" vapor-deposited aluminum (VDA) in the outermost radiation shield was especially challenging. It was accomplished by applying conductive ink to the shield edges to electricaliy join the hidden VDA with the exposed VDA on the underside of the outer shield.

Finally, the most difficult task involved demonstrating that the insulated liquid-hydrogen tank would be safe if the helium purge was lost during a abort. Two functions critical to providing helium during an abort and descent were (1) the closure of the abort vent door in the forward adapter to allow repressur1zation of the insulation blanket with hellum and (2) the operation of the hellum purge supply. Although, many of the elements of both systems were twofallure tolerant (e.g., dual pyrotechnics for the vent door pin puller, three $\Delta P$ transducers, and redundant software), there were remote situations where a single fallure could cause loss of hellum purge. These functions could have been made two-fallure tolerant but not without additional weight and complex1ty. Therefore a considerable effort was spent looking at the effects of ingesting air into the liquid-hydrogen-tank insulation system. Tests demonstrated that no liquid nitrogen or liquid air would form on the outside of the shields even if colder liquid nitrogen was contained within the inner shield. So even with a fallure of the purge supply to the insulation, the shuttle could land without the hazard of the cargo bay being exposed to liquid nitrogen or liquid air.

However, since there was a possiblilty of having liquid alr within the insulation blanket after a single fallure, it had to be demonstrated that the system was benign to possible impacts. Efforts were under way to demonstrate the impact sensitivity of the insulation system with low-pressure (1 atm) 11quid air or gaseous oxygen contained in the system when the shuttle/Centaur program was canceled. The preliminary test results taken at a pressure of 50 psia were mixed but looked promising. We felt that there was a good possiblilty of the system being benign to impacts when tested as a system at atmospheric pressures. If not, additional redundancy would have been required for the hellum purge system. 
In summary, the comblined helium-purged foam and radiation shield system used for the Centaur G-prime liquid-hydrogen tank proved to be an effective lightweight method of providing thermal protection during both ground-hold and on-orbit operations. The technology and information generated under this developmental effort should be directly applicable to the design of cryogenic thermal protection systems for future shuttle or upper stage applications.

\section{REFERENCES}

1. Spurlock, 0.F., "Shuttle/Centaur - More Capability for the 1980's," IAF Paper 83-18, Oct. 1983.

2. "Atlas-Centaur AC-19 and AC-20 Performance for the 1969 Mariner Mars Missions," NASA TM X-2278, 1971.

3. Lacovic, R.F., "Thermodynamic Data Report for the Titan/Centaur TC-5 Extended Mission," NASA TM X-73605, 1977.

4. "Safety Policy and Requirements for Payloads Using the Space Transportation System (STS)," NASA TM-85402, 1982. (NHB-1700.7A.)

5. "Payload Ground Safety Handbook," KHB-1700.7, Rev. A.

6. "Shuttle System Requirements for Shuttle Centaur Stage and Atrborne Support Equipment," NASA Johnson Space Center, JCS-07700, Vol. X, Appendix 10.16, Dec. 1985.

7. "Flammab1lity, Odor, and Dutgassing Requirements and Test Procedures for Materials in Environments That Support Combustion," NASA TM-84066, 1981. (NHB-8060.18.)

8. Pleasant, R.L., "Heat-Transfer Through Liquid-Hydrogen Tank Insulation on Shuttle/Centaur G-Prime," Cryogentc Properties. Processes and Applications 1986 , A.J. Kldnay and M.J. H1za, eds.. AIChE, New York, 1986, Dp. 75-80. (AIChE Sympostum Series, Vol. 82, No. 251.)

9. Magison, E.C., Electrical Instruments in Hazardous Locations, Third Revised Edition, Instrument Society of America, Pittsburgh, 1978. 
TABLE I. - RADIATION-SHIELD DETAILS FOR G-PRIME LIQUIO-HYDROGEN TANK

\begin{tabular}{|c|c|c|c|c|}
\hline $\begin{array}{l}\text { Basic shield } \\
\text { material }\end{array}$ & $\begin{array}{l}\text { Dutboard } \\
\text { surface } \\
\text { materlal }\end{array}$ & $\begin{array}{l}\text { Inboard } \\
\text { surface } \\
\text { material }\end{array}$ & Area of use & $\begin{array}{l}\text { Unit weight, } \\
\qquad \mathrm{lb} / \mathrm{ft}^{2}\end{array}$ \\
\hline Embossed Kapton & VDAd & VDA & $\begin{array}{l}\text { Middle (center) shield } \\
\text { on purge diaphragm, } \\
\text { forward bulkhead } \\
\text { shlelds, and sidewall } \\
\text { shlelds }\end{array}$ & 0.0022 \\
\hline Kapton sheet & VDA & VDA & $\begin{array}{l}\text { Inboard shle?d on } \\
\text { forward bulkhead }\end{array}$ & .0022 \\
\hline $\begin{array}{l}\text { Kevlar cloth } \\
\text { laminate }\end{array}$ & $\begin{array}{l}\text { VDA-Kapton } \\
(0.5 \mathrm{mil})\end{array}$ & $\begin{array}{l}\text { Kapton-VDA } \\
(0.5 \mathrm{mil})\end{array}$ & $\begin{array}{l}\text { Outboard and inboard } \\
\text { shlelds of purge } \\
\text { diaphragm and inboard } \\
\text { shleld on sidewall }\end{array}$ & .04 \\
\hline $\begin{array}{l}\text { Kevlar cloth } \\
\text { laminate }\end{array}$ & $\begin{array}{l}\text { Tef lon-VDA } \\
(0.5 \mathrm{mll})\end{array}$ & $\begin{array}{l}\text { Kapton-VDA } \\
(0.5 \mathrm{mil})\end{array}$ & $\begin{array}{l}\text { Outboard shield of } \\
\text { itquid-hydrogen- } \\
\text { tank sidewall }\end{array}$ & .04 \\
\hline $\begin{array}{l}\text { Nomex scrim } \\
\text { laminate }\end{array}$ & $\begin{array}{l}\text { VDA-Kapton } \\
\left(0.3 \mathrm{~m}^{1} 1\right)\end{array}$ & $\begin{array}{l}\text { Kapton-VDA } \\
(0.3 \mathrm{~m} 11)\end{array}$ & $\begin{array}{l}\text { Outboard shield on } \\
\text { forward bulkhead }\end{array}$ & .02 \\
\hline
\end{tabular}

avapor-deposited aluminum.

TABLE II. - SHUTTLE/CENTAUR G-PRIME LIQUID-HYDROGEN-TANK STEADY-STATE HEATING DURING PRELAUNCH OPERATIONS ANO OURING ON-ORBIT PORTION OF GALILEO MISSION (OPEN DOOR, PREDEPLOYMENTA)

\begin{tabular}{|c|c|c|c|c|c|}
\hline & \multicolumn{2}{|c|}{ Prelaunchb } & \multicolumn{3}{|c|}{ On-orb1t } \\
\hline & Maximum & Minimum & Maximum & Nomtnal & Hintmum \\
\hline & \multicolumn{5}{|c|}{ Heating rate, Btu/hr } \\
\hline $\begin{array}{l}\text { Forward bulkhead } \\
\text { Forward adapter } \\
\text { Sidewall } \\
\text { Penetrations } \\
\text { Intermedlate bulkhead } \\
\text { Gaseous-hellum purge } \\
\text { Total }\end{array}$ & $\begin{array}{rr}20 & 600 \\
7 & 500 \\
49 & 970 \\
4 & 085 \\
1 & 835 \\
4 & 445 \\
88 & 435\end{array}$ & $\begin{array}{rl}19 & 600 \\
5 & 700 \\
45 & 000 \\
4 & 085 \\
1 & 115 \\
2 & 440 \\
77 & 940\end{array}$ & \begin{tabular}{r}
202 \\
121 \\
671 \\
407 \\
1835 \\
\hdashline-0 \\
3221
\end{tabular} & $\begin{array}{r}184 \\
110 \\
610 \\
370 \\
1475 \\
---- \\
2735\end{array}$ & $\begin{array}{r}165 \\
99 \\
549 \\
333 \\
1115 \\
-2249\end{array}$ \\
\hline
\end{tabular}

apayload doors open with orblter tall orlented to Earth.

bCargo bay gaseous-nitrogen inlet temperature of $55^{\circ} \mathrm{F}$ at flow rate of $180 \mathrm{lb} / \mathrm{min}$ past iqquid-hydragen-tank sidewall.

TABLE III. - STRUCTURAL TEST RESULTS ON SIOEWALL SHIELD MATERIALS ANO SEWN JOLNTS

(a) Basic matertal tests

\begin{tabular}{|l|c|c|c|}
\hline \multicolumn{1}{|c|}{ Laminate } & $\begin{array}{c}\text { Tensile strength, } \\
\text { ib/in. }\end{array}$ & $\begin{array}{c}\text { Tensile strengtha } \\
\text { (creased). } \\
\text { (b/1n. }\end{array}$ & $\begin{array}{c}\text { Modulus, } \\
\text { E, } \\
\text { lo/in. }\end{array}$ \\
\hline $\begin{array}{l}\text { Fiberglass } \\
\text { Kevlar }\end{array}$ & 154 & 33 & 3173 \\
& 239 & 191 & 7767 \\
\hline
\end{tabular}

(b) Pull tests on sewn seams

\begin{tabular}{|c|c|c|}
\hline Type of seam & Description & $\begin{array}{c}\text { Tensile strengtha } \\
\text { (at fallure), } \\
\text { lb/in. }\end{array}$ \\
\hline $\begin{array}{l}\text { Overlap with two rows } \\
\text { of stitching (Kevlar) }\end{array}$ & $\begin{array}{c}\text { Shield sewn to shield: } \\
\text { Warp direction } \\
\text { Fill direction } \\
\text { Shield to edge member } \\
\text { (warp direction) }\end{array}$ & 231 \\
& 213 \\
\hline
\end{tabular}

adesign requires $43.5 \mathrm{lb} / 1 \mathrm{n}$. at $\Delta P=0.5 \mathrm{ps} 1 \mathrm{~d}$. 
TABLE IV. - SHUTTLE/CENTAUR G-PRIME RADIATION SHIELO SURFACE PROPERTY REQUIREMENTS ANO MEASUREMENTS

\begin{tabular}{|c|c|c|c|c|}
\hline \multirow[t]{2}{*}{$\begin{array}{c}\text { Outer surface } \\
\text { material }\end{array}$} & \multicolumn{2}{|c|}{$\begin{array}{c}\text { Spectfication } \\
\text { values }\end{array}$} & \multicolumn{2}{|c|}{$\begin{array}{c}\text { Averaged measured } \\
\text { valuesa }\end{array}$} \\
\hline & $\begin{array}{l}\text { Therma } \\
\text { emittance }\end{array}$ & $\begin{array}{c}\text { Solar } \\
\text { absorptance }\end{array}$ & $\begin{array}{c}\text { Therma } 1 \\
\text { emittance }\end{array}$ & $\begin{array}{c}\text { Solar } \\
\text { absorptance }\end{array}$ \\
\hline \multicolumn{5}{|c|}{ sntelds } \\
\hline $\begin{array}{l}\text { Teflon-VOA } \\
\text { VOA-Kapton } \\
\text { Flberglass }\end{array}$ & $\begin{array}{l}\geq 0.40 \\
\leq .05 \\
\geq . .81\end{array}$ & $\begin{array}{l}\leq 0.14 \\
\leq .14 \\
\leq .35\end{array}$ & $\begin{array}{r}0.44 \\
.04 \\
.88\end{array}$ & $\begin{array}{l}0.132 \\
.09 \\
.31\end{array}$ \\
\hline \multicolumn{5}{|c|}{ Tapes } \\
\hline $\begin{array}{l}\text { Teflon-VOA } \\
\text { A1uminized Kapton }\end{array}$ & $\begin{array}{l}\geq 0.40 \\
\leq .05\end{array}$ & $\begin{array}{l}\leq 0.14 \\
\leq .14\end{array}$ & $\begin{array}{l}0.46 \\
.043\end{array}$ & $\begin{array}{l}0.12 \\
.134\end{array}$ \\
\hline
\end{tabular}

ameasurements were made using a Lion Research Corp. reflectometer/emissometer model E25B.

TABLE V. - CARGO BAY VENT FLOW RATES AND TEST FLOW RATES FOR VARIOUS SHUTTLE FLIGHT EVENTS

\begin{tabular}{|c|c|c|c|c|c|c|c|c|c|}
\hline \multirow{2}{*}{$\begin{array}{l}\text { Cargo } \\
\text { bay } \\
\text { vent }\end{array}$} & \multicolumn{6}{|c|}{ flighta } & \multicolumn{3}{|c|}{ Test inflow at sea level } \\
\hline & Phase & $\begin{array}{c}\text { Flow } \\
\text { direction }\end{array}$ & $\begin{array}{c}\text { Altitude, } \\
\mathrm{ft}\end{array}$ & $\begin{array}{c}\text { velocity, } \\
v, \\
\mathrm{ft} / \mathrm{sec}\end{array}$ & $\begin{array}{c}\text { Dynamic } \\
\text { pressure. } \\
q, \\
i b / f t^{2}\end{array}$ & $\begin{array}{c}\text { Insula- } \\
\text { tion } \\
\text { pres- } \\
\text { surized? }\end{array}$ & $\begin{array}{c}\text { velocity, } \\
v \text {. } \\
\mathrm{ft} / \mathrm{sec}\end{array}$ & $\begin{array}{c}\text { Dynamic } \\
\text { pressure, } \\
q, \\
\mathrm{lb} / \mathrm{ft}^{2}\end{array}$ & $\begin{array}{l}\text { Insula- } \\
\text { tion } \\
\text { pres- } \\
\text { surized? }\end{array}$ \\
\hline $\begin{array}{l}6 \\
5 \\
6 \\
6 \\
5 \\
5\end{array}$ & $\begin{array}{c}\text { Ascent } \\
\text { Ascent } \\
\text { Descent }\end{array}$ & $\begin{array}{l}\text { Out } \\
\text { In } \\
\text { Out } \\
\text { In } \\
\text { In } \\
\text { In }\end{array}$ & $\begin{array}{l}20 \times 10^{3} \\
14 \\
30 \\
72.5 \\
72.5 \\
28\end{array}$ & $\begin{array}{r}130 \\
210 \\
90 \\
1420 \\
970 \\
550\end{array}$ & $\begin{array}{r}11 \\
33 \\
2 \\
40 \\
18 \\
130\end{array}$ & $\begin{array}{l}\text { No } \\
\text { No } \\
\text { Yes } \\
\mid\end{array}$ & $\begin{array}{l}130 \\
210 \\
391 \\
-2 \\
--- \\
391\end{array}$ & $\begin{array}{r}20 \\
52 \\
182 \\
--- \\
-- \\
182\end{array}$ & \begin{tabular}{l} 
No \\
No \\
Yes \\
$-\cdots$ \\
\hdashline-- \\
Yes
\end{tabular} \\
\hline
\end{tabular}

aRockwell International data presented at Centaur G-prime design review. bsafety factor of 1.4 applied to flight a of $130 \mathrm{lb} / \mathrm{ft}^{2}$.

TABLE VI. - IMPACI SENSITIVIIY OF LIQUIO-HYDROGEN-TANK SIOEWALL INSULAIION SYSIEM MATERIALS IN LOW. PRESSURE GASEOUS OXYGEN

[Test medium, 100 percent gaseous oxygen; test pressure, 50 psía. See ref. 7 for a description of the test procedures.]

\begin{tabular}{|c|c|c|c|c|}
\hline Material & $\begin{array}{l}\text { WSifa } \\
\text { test } \\
\text { report }\end{array}$ & $\begin{array}{c}\text { Impact } \\
\text { energy, } \\
f t-i b\end{array}$ & $\begin{array}{c}\text { Number } \\
\text { of } \\
\text { reactions }\end{array}$ & $\begin{array}{c}\text { Number } \\
\text { of } \\
\text { tests }\end{array}$ \\
\hline Polytmide foam & $86-20077$ & $\begin{array}{l}72 \\
65 \\
60 \\
55 \\
50 \\
45 \\
40 \\
35 \\
30 \\
25 \\
20\end{array}$ & $\begin{array}{l}2 \\
1 \\
1 \\
0\end{array}$ & $\begin{array}{r}2 \\
1 \\
1 \\
1 \\
2 \\
1 \\
8 \\
20\end{array}$ \\
\hline $\begin{array}{l}\text { Inner shield material (Kevlar } \\
\text { cloth laminate) }\end{array}$ & $85-20076$ & 72 & 0 & 20 \\
\hline $\begin{array}{l}\text { Taped seam from three-layer } \\
\text { sidewall shield }\end{array}$ & $86-20078$ & $\begin{array}{l}72 \\
65 \\
60 \\
55 \\
40 \\
30 \\
25 \\
20 \\
15\end{array}$ & $\begin{array}{l}2 \\
1 \\
1 \\
0\end{array}$ & $\begin{array}{r}3 \\
1 \\
1 \\
5 \\
19 \\
2 \\
20\end{array}$ \\
\hline
\end{tabular}

ajohnson Space Center white Sands Test Factlity. 


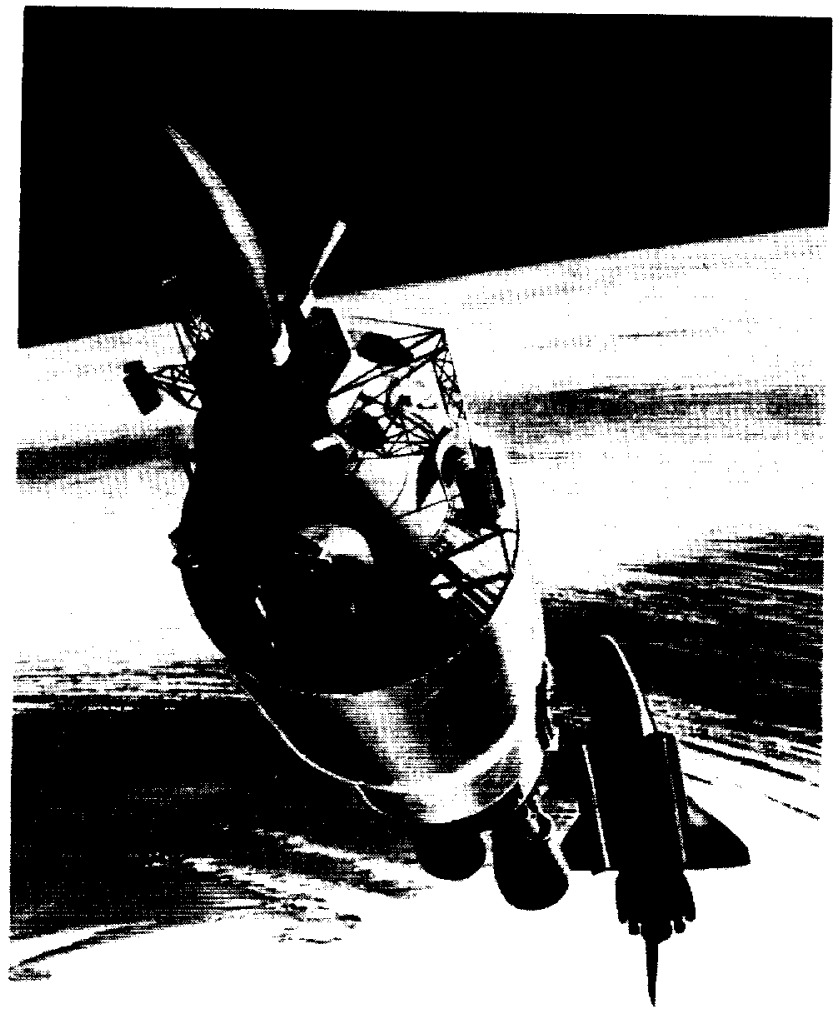

ORIGINAL PAGE IS OF POOR QUALITY

FIGURE 1. - SEPARATION OF SHUTTLE/CENTAUR G-PRIME FROM SHUTTLE VEHICLE IN ORBIT,

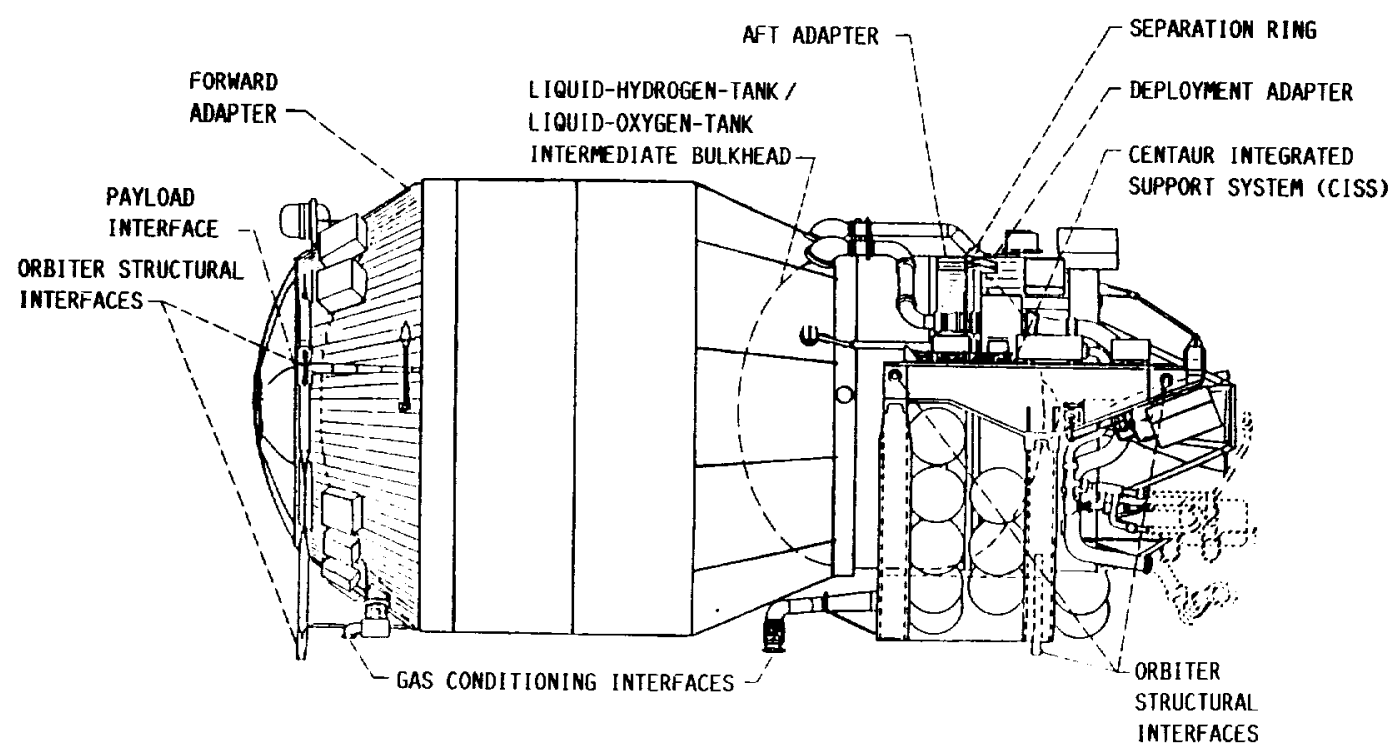

FIGURE 2. - SHUTTLE/CENTAUR G-PRIME CONFIGURATION AND MAJOR STRUCTURAL INTERFACES, 


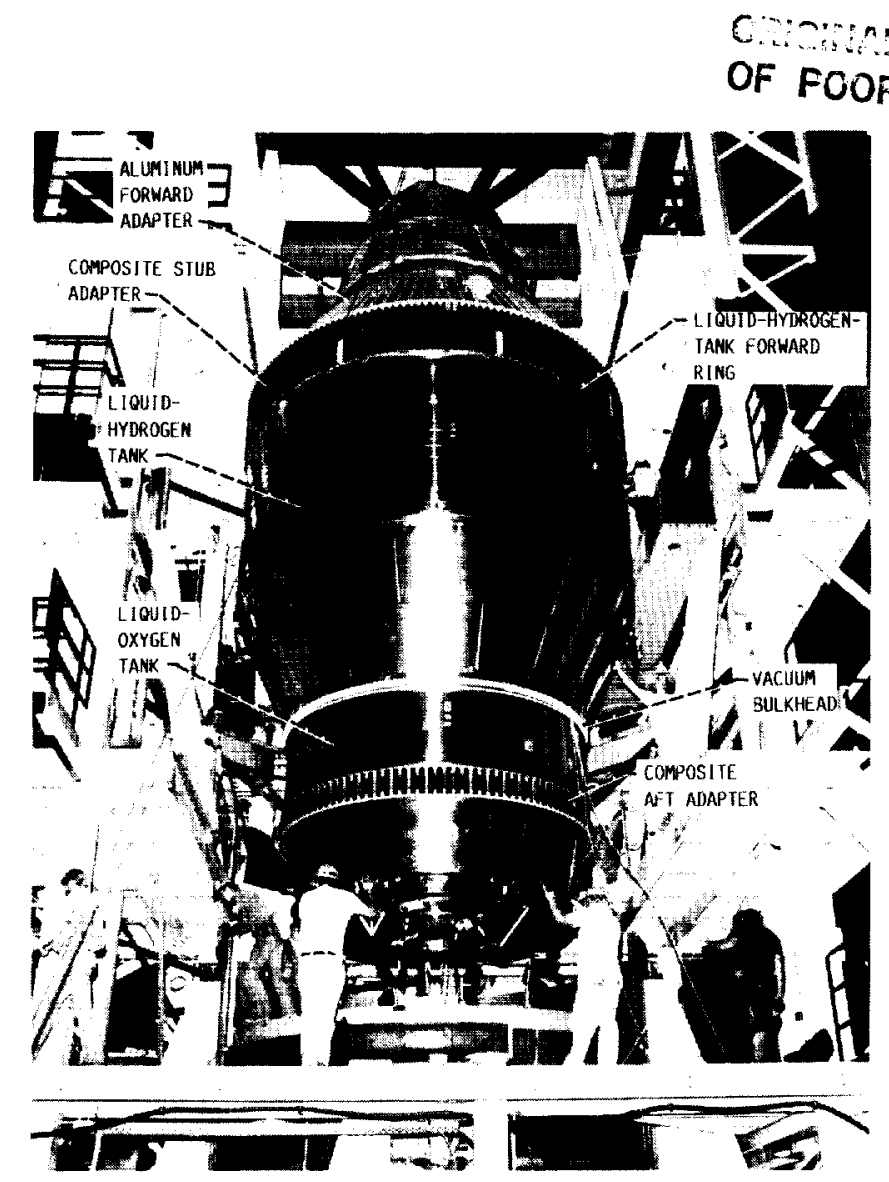

FIGURE 3. - BASIC SHUTILE/CENIAUR G-PRIME VEHICLE CONFIGURATION (BEFORE INSTALLATION OF THERMAL PROTECTION SYSTEMS AND FLIGHI HARDWARE?.

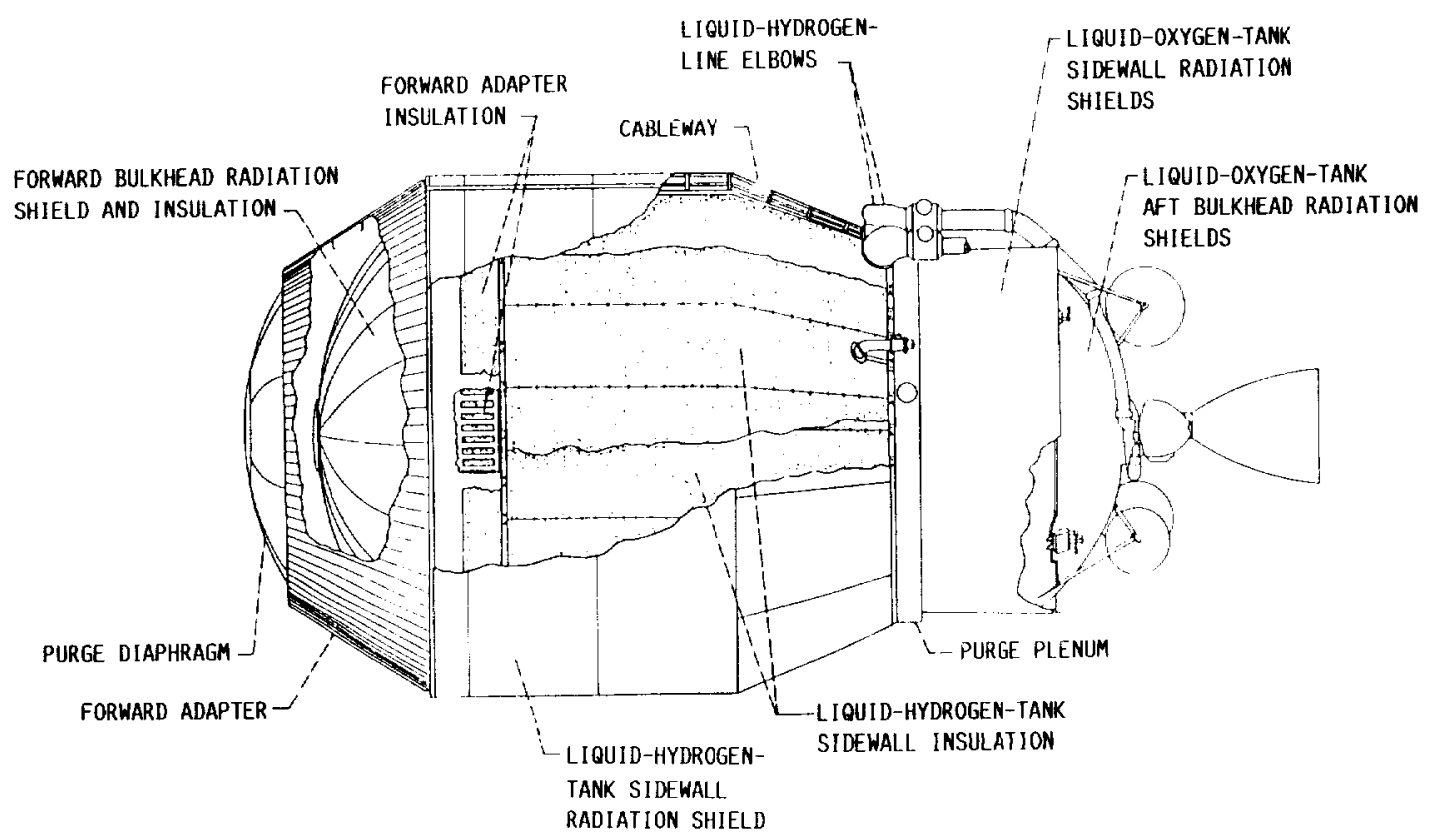

FIGURE 4.- SHUTTLE/CENTAUR G-PRIME THERMAL PROTECTION SYSTEMS. 


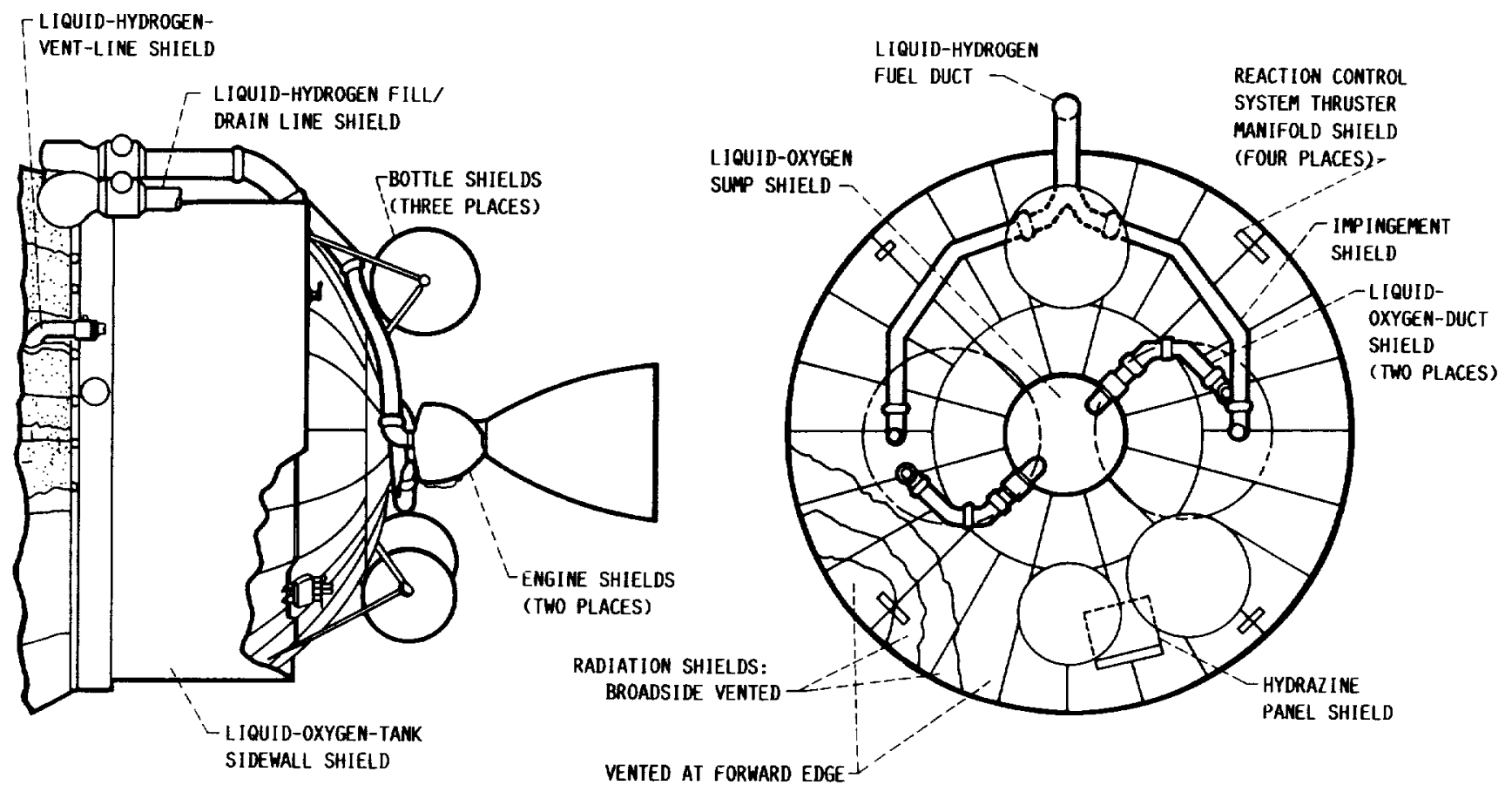

FIGURE 5.- AFT-END THERMAL PROTECTION OF SHUTTLE/CENTAUR G-PRINE VEHICLE.

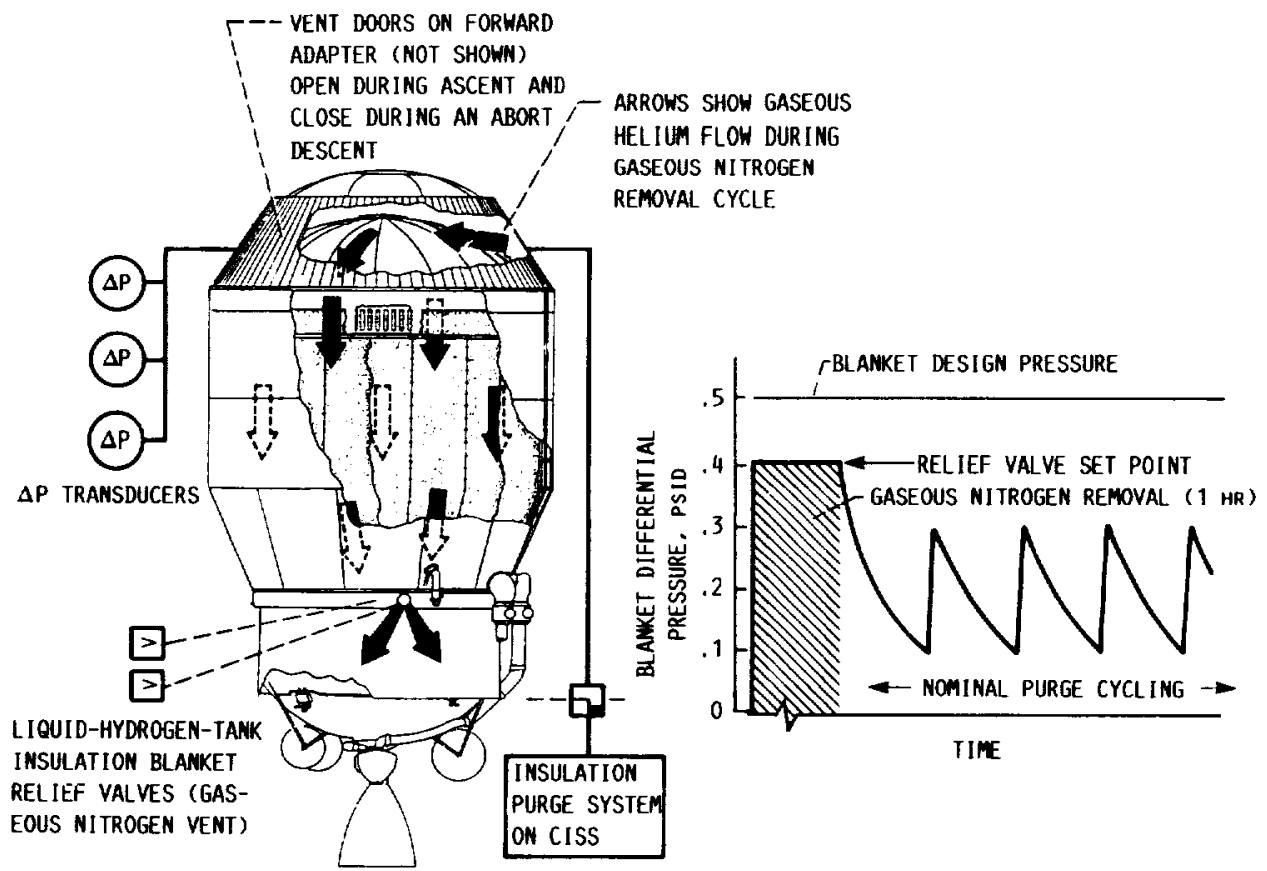

FIGURE 6. - INSULATION BLANKET PURGE SYSTEM OPERATION FOR SHUTTLE/CENTAUR G-PRIME LIQUIDHYDROGEN TANK. 


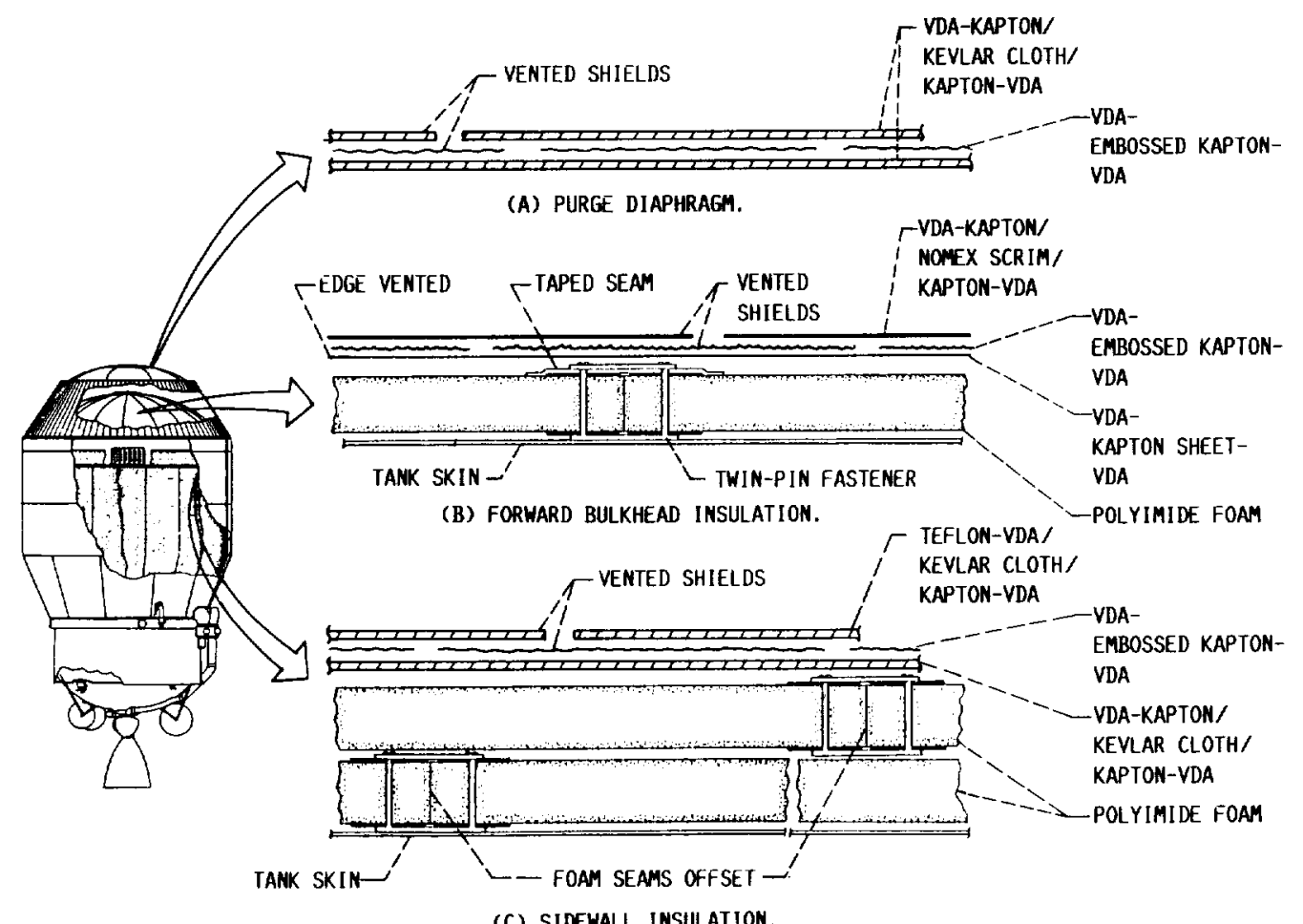

FIGURE 7. - PRIMARY THERMAL PROIECTION SYSTEMS USED ON SHUTTLE/CENTAUR G-PRIFE LIQUID-HYDROGEN TANK.
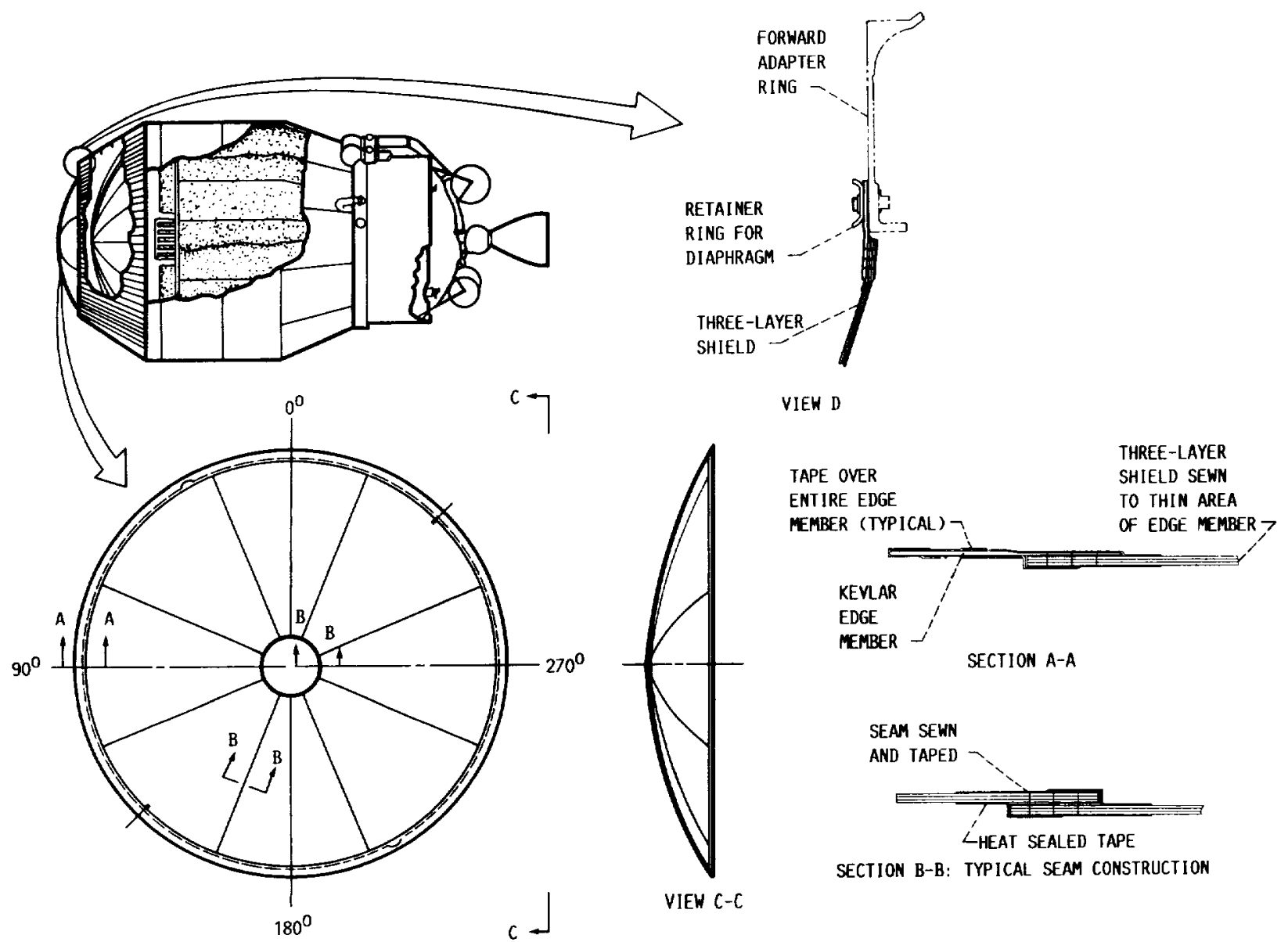

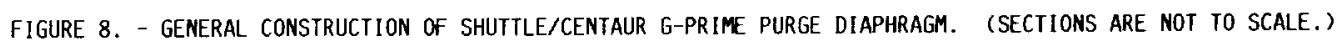




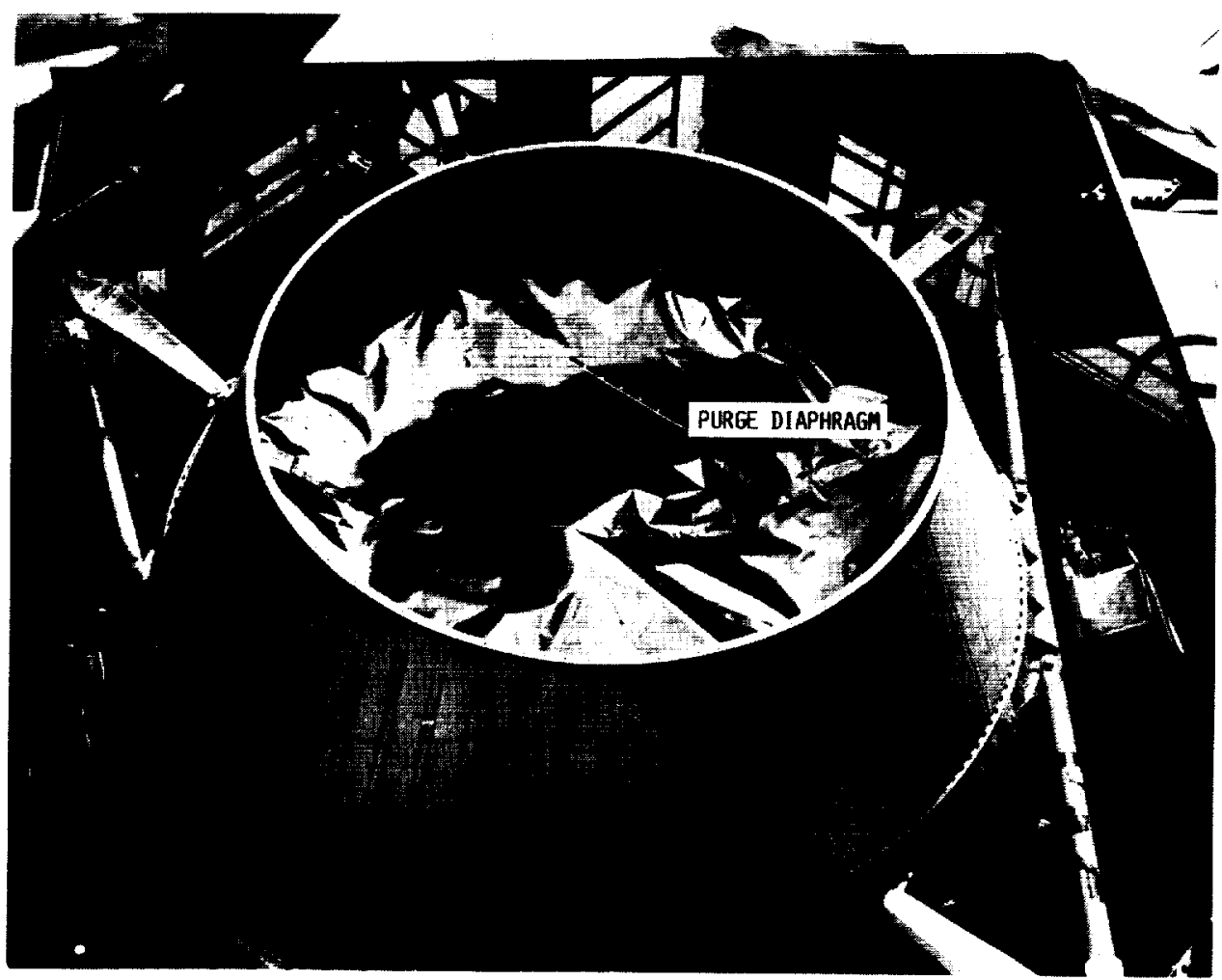

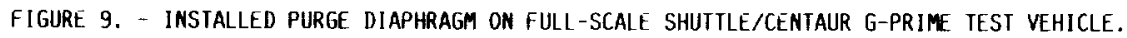
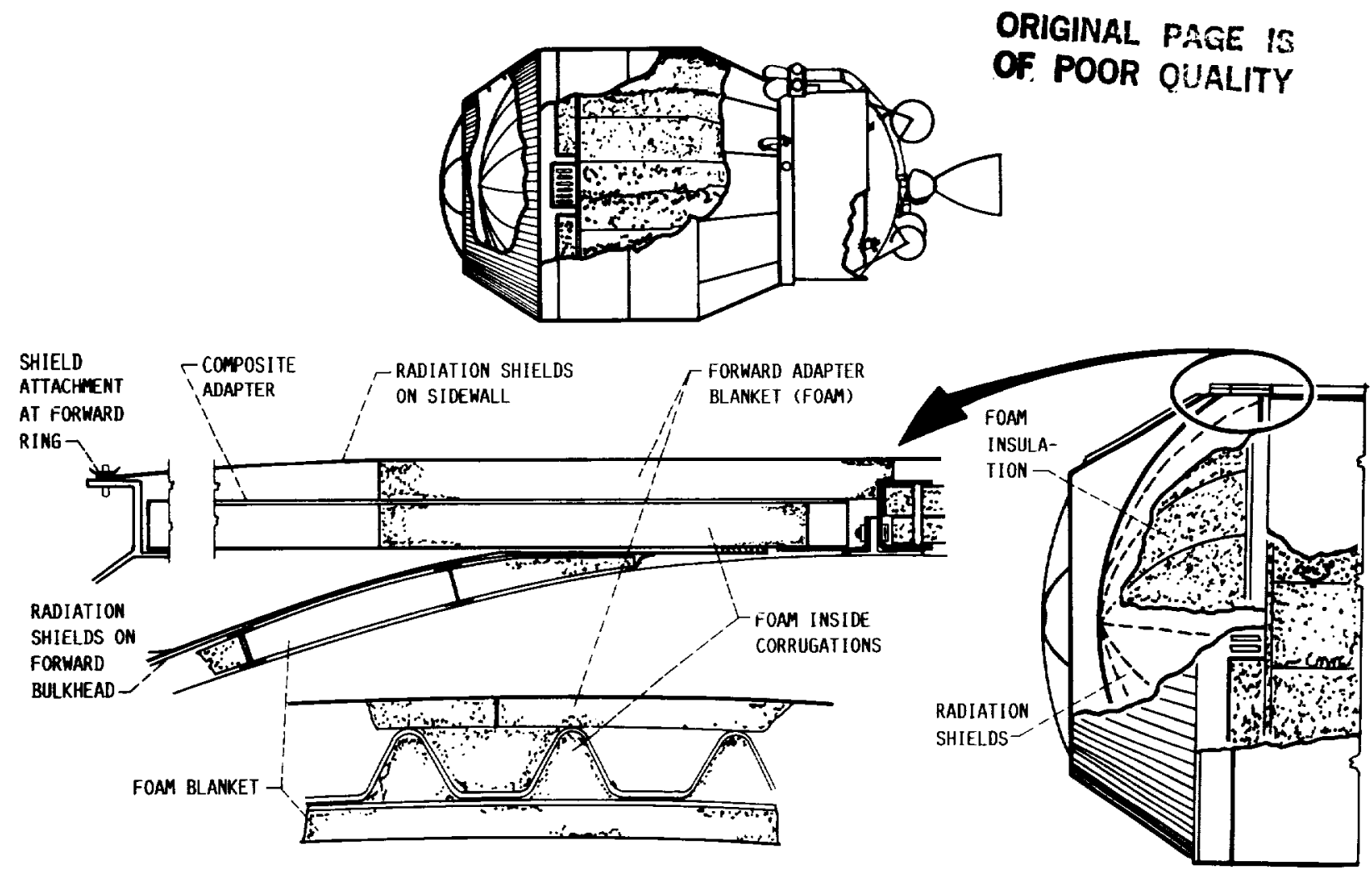

FIGURE 10. - INSULATION DETAILS ON FORHARD END OF SHUTTLE/CENTAUR G-PRIME LIQUID-HYDROGEN TAMK. (POLYIMIDE FOAM USED THROUGHOUT.) 
ORIGNAL FiOE :S

OF POOR QUALITY

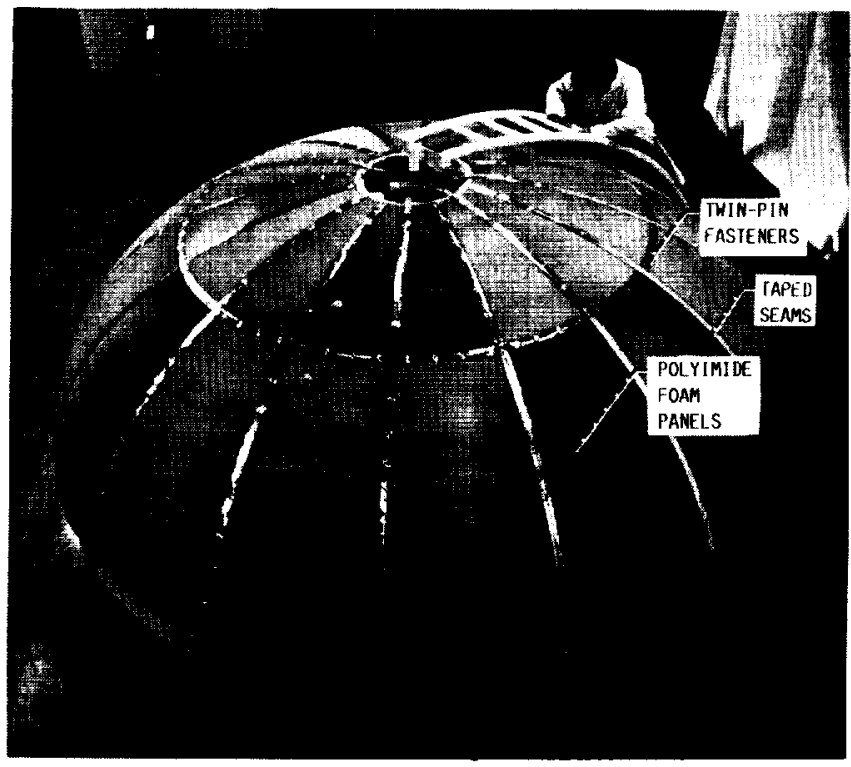

FIGURE 11. - LAYUP OF POLYIMIDE FOAM FOR FORMARD BULKHEAD OF SHUTTLE/CENTAUR GPRIME TEST TANK. 


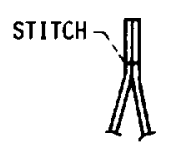

STEP 1

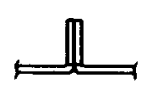

STEP 2

SECTION A-A: TYPICAL SEAM CONSTRUCTION

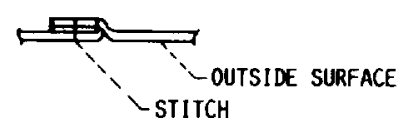

STEP 3

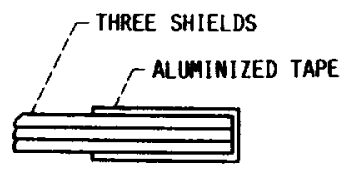

SECTION C-C: TYPICAL EDGE TREATRENT FOR GORE SECTORS

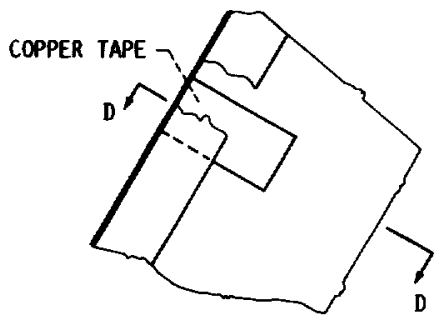

YIEW B

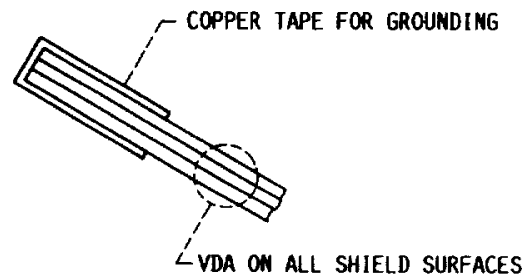

SECIION D-D

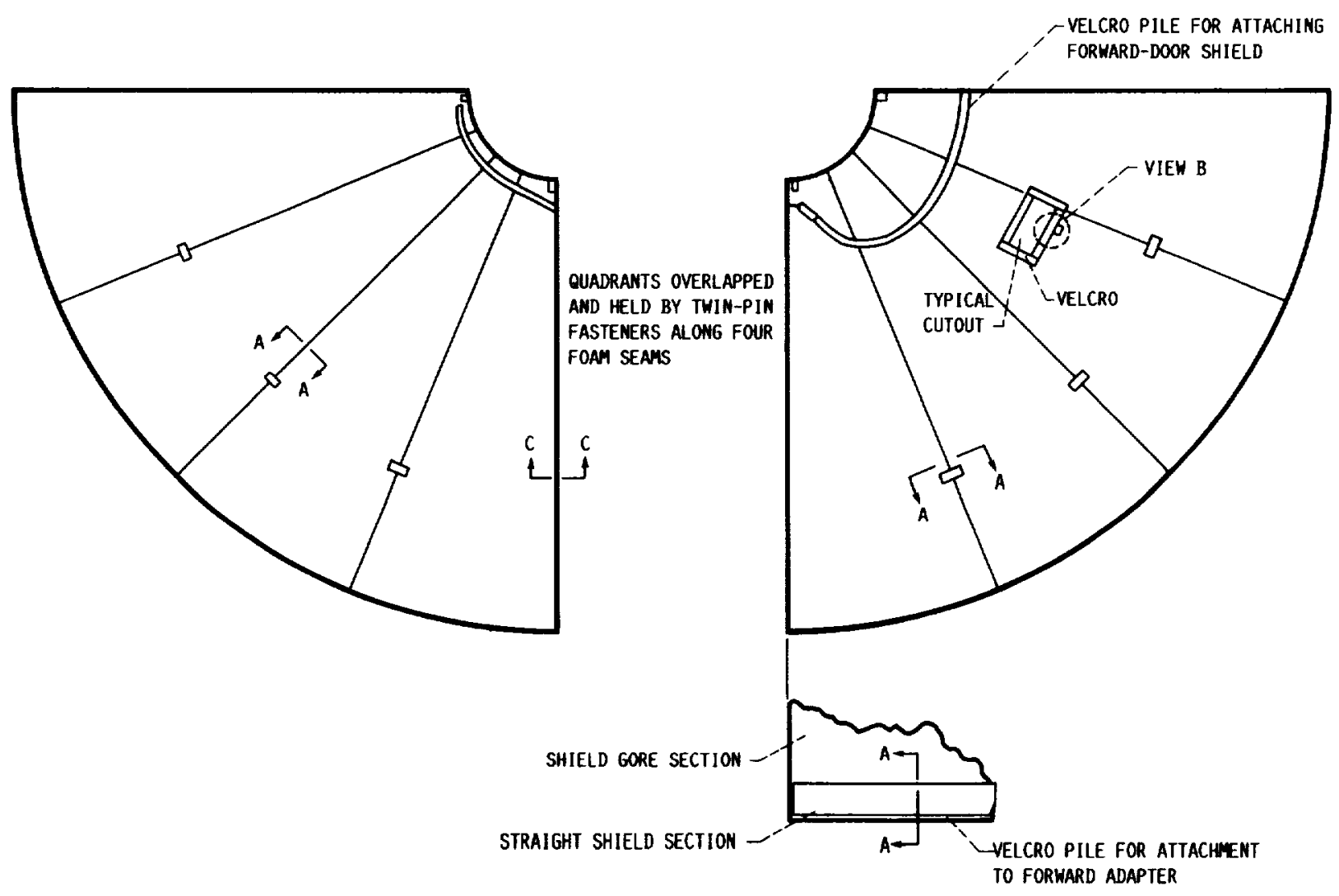

FIGURE 12. - GENERAL CONSTRUCTION OF SHUTTLE/CENTAUR G-PRIME FORHARD BULKHEAD RADIATION SHIELDS. CONLY TWO QUADRANTS SHOWH FOR BREVITY. SECTIONS ARE NOT TO SCALE.) 


\section{ORIGINA PNEE 13 \\ OF POOR QUALITY}

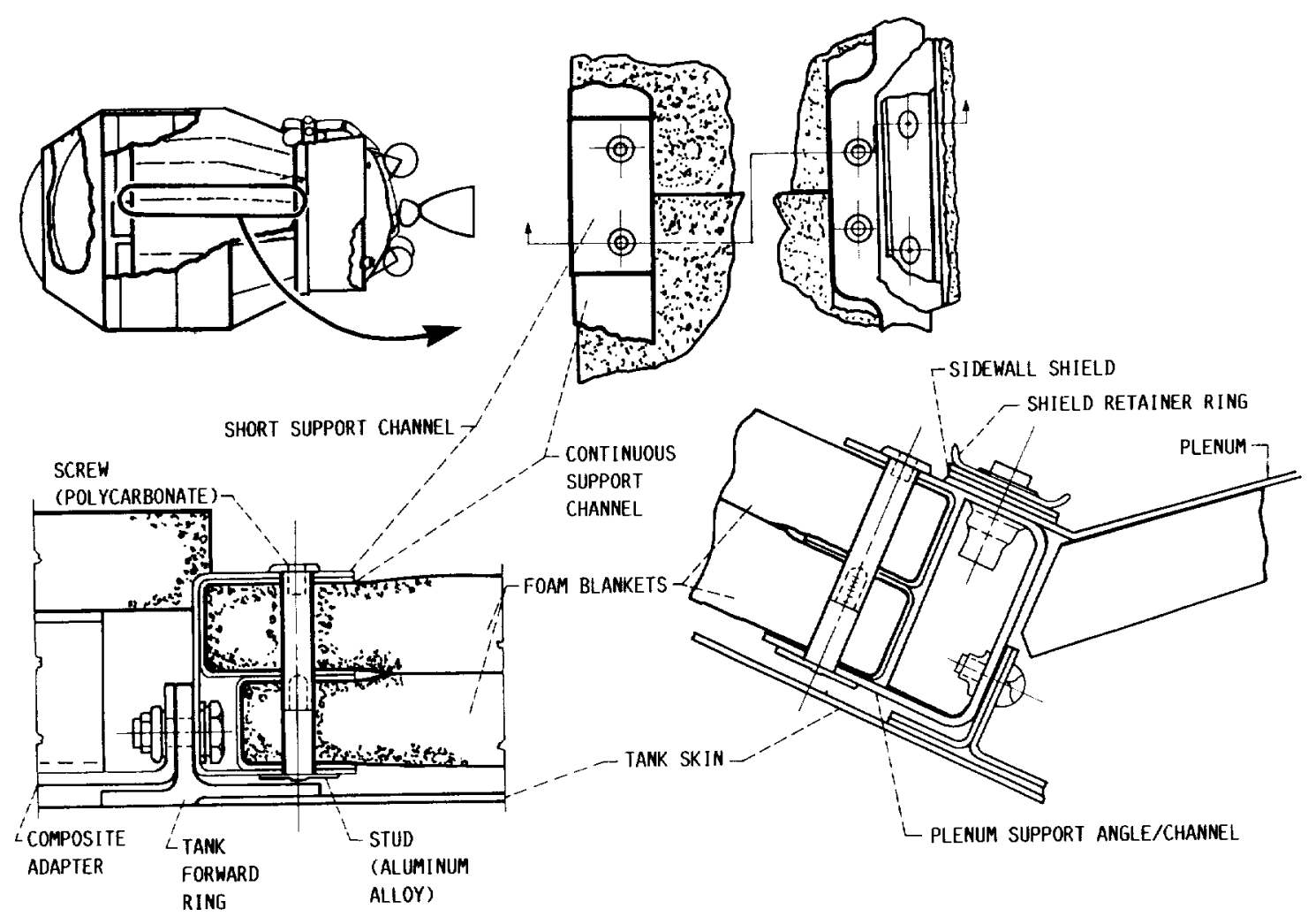

FIGURE 13. - DETAILS OF POLYIMIDE FOAM ATTACHMENT FOR SHUTTLE/CENTAUR G-PRIME LIQUID-HYBROGEN TANK.

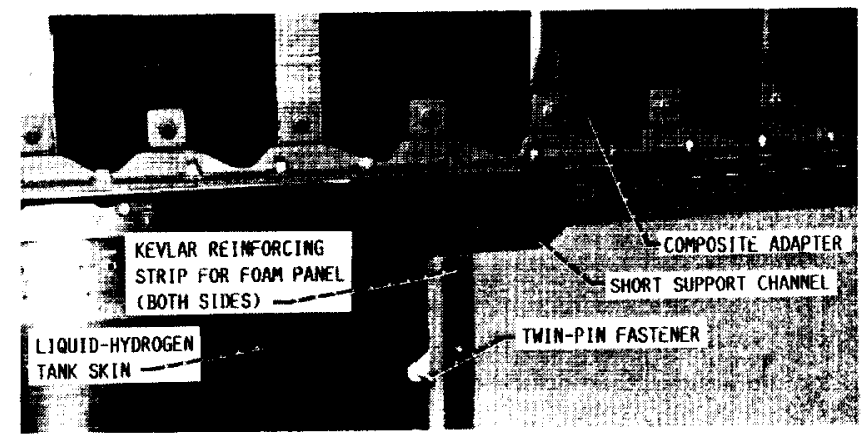

FIGURE 14. - ATIACHAENT OF POLYIMIDE FOAM PANELS AT FORWARD RING OF SHUTILE/CENIAUR G-PRIME LIQUID-HYDROGEN TANK. 


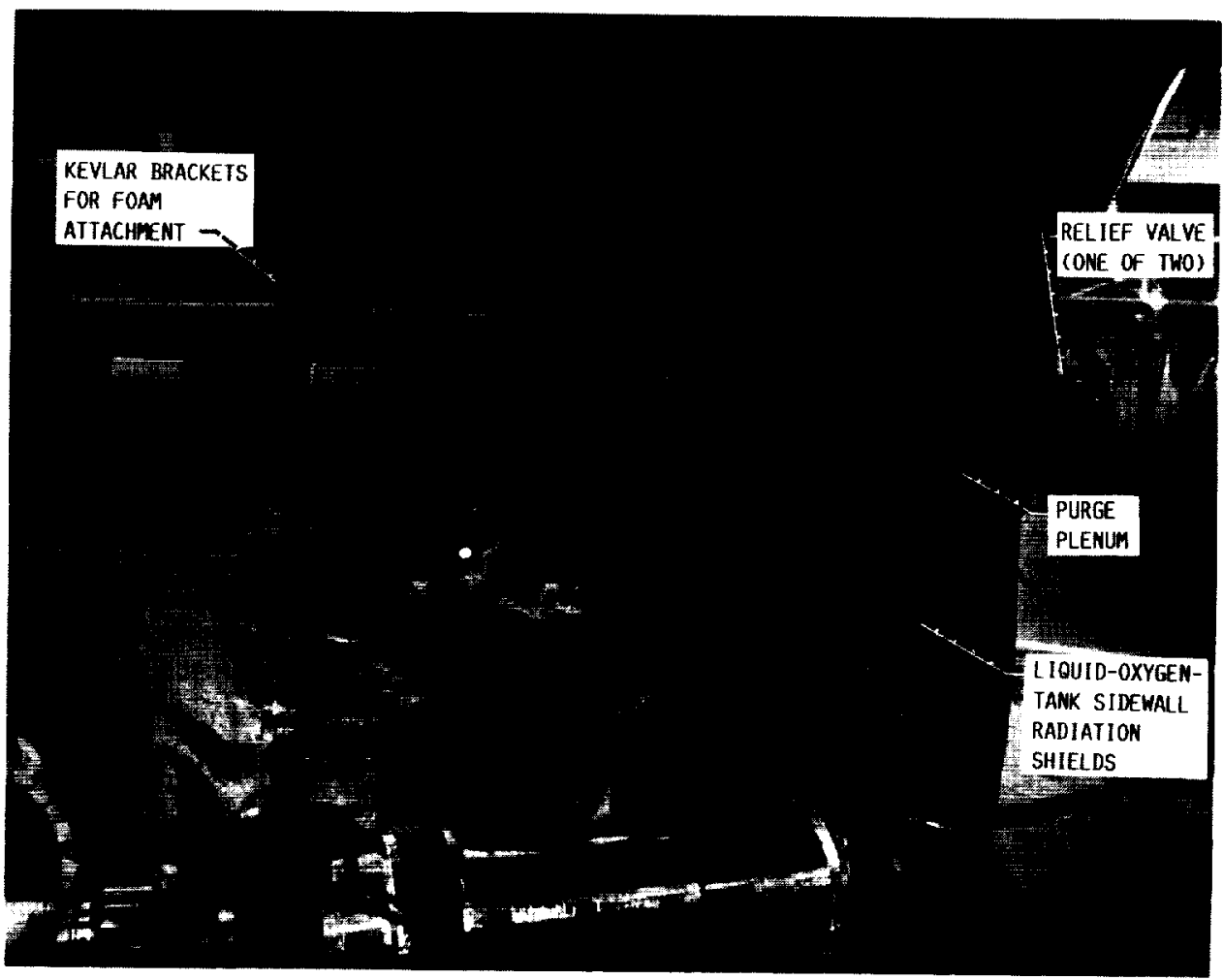

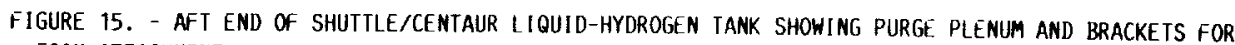
FOAM ATTACHMENT.

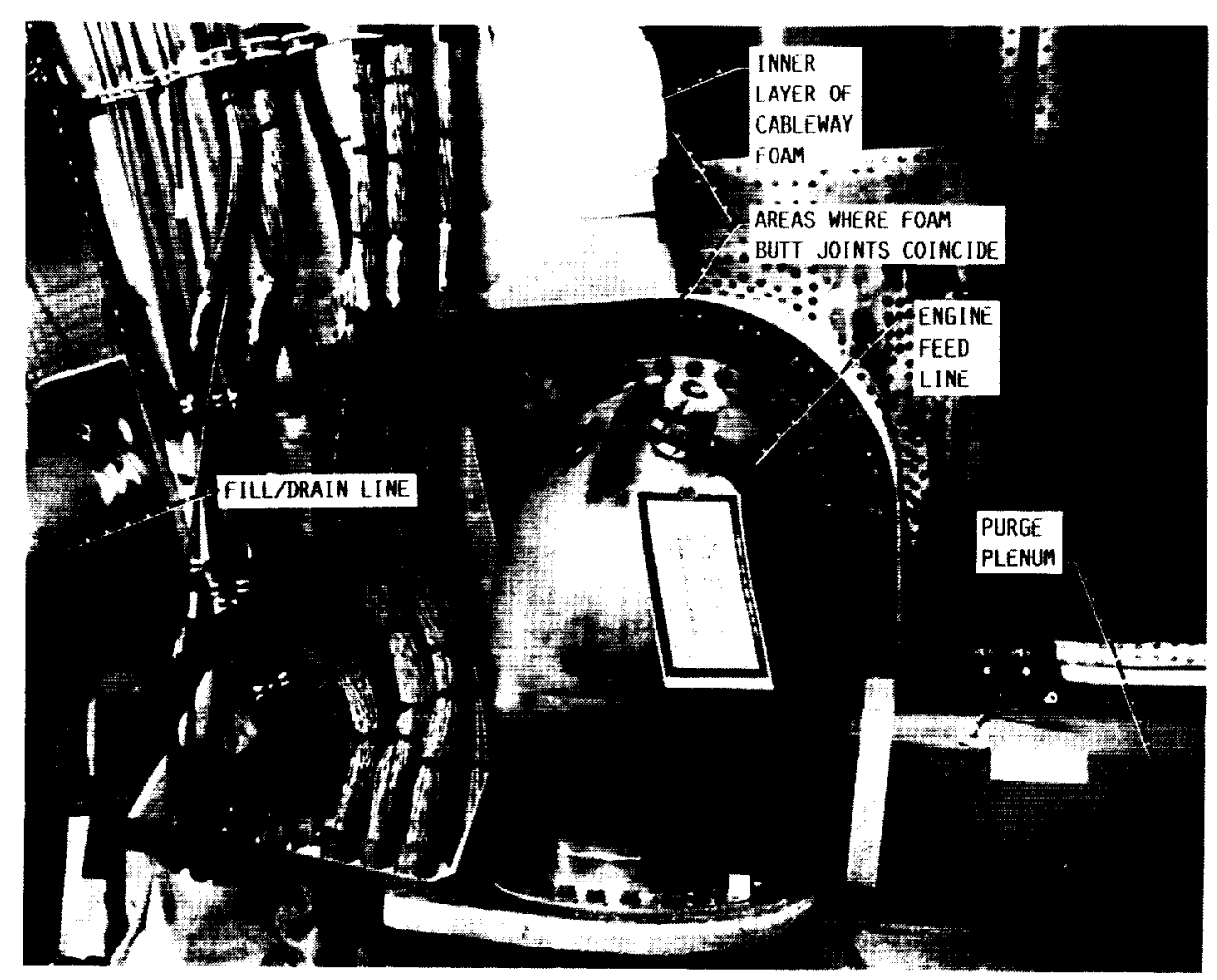

FIGURE 16. - AFT END OF CABLEWAY AREA. 


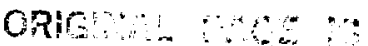

OF POOR QUALIT
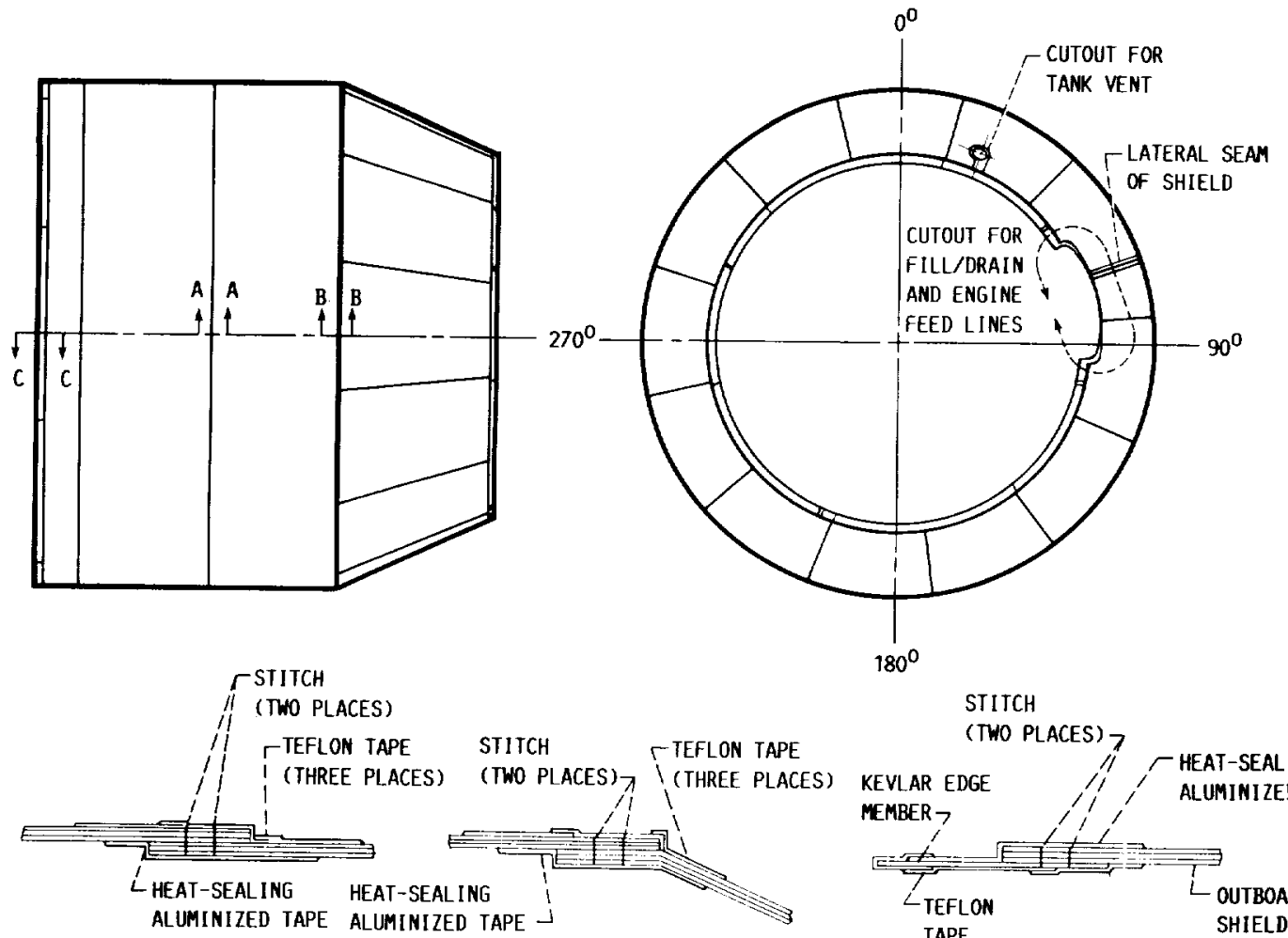

STITCH

(TWO PLACES) 7

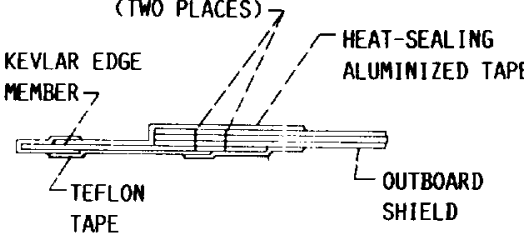

SECTION A-A: TYPICAL SEWN JOINT

SECTION B-B

SECTION C-C: TYPICAL SHIELD EDGE

FIGURE 17. - GENERAL DETAILS OF SHUTTLE/CENTAUR G-PRIME LIQUID-MYDROGEN-TANK SIDEWALL SHIELD CONSTRUCTION. (SECTIONS ARE NOT TO SCALE.)

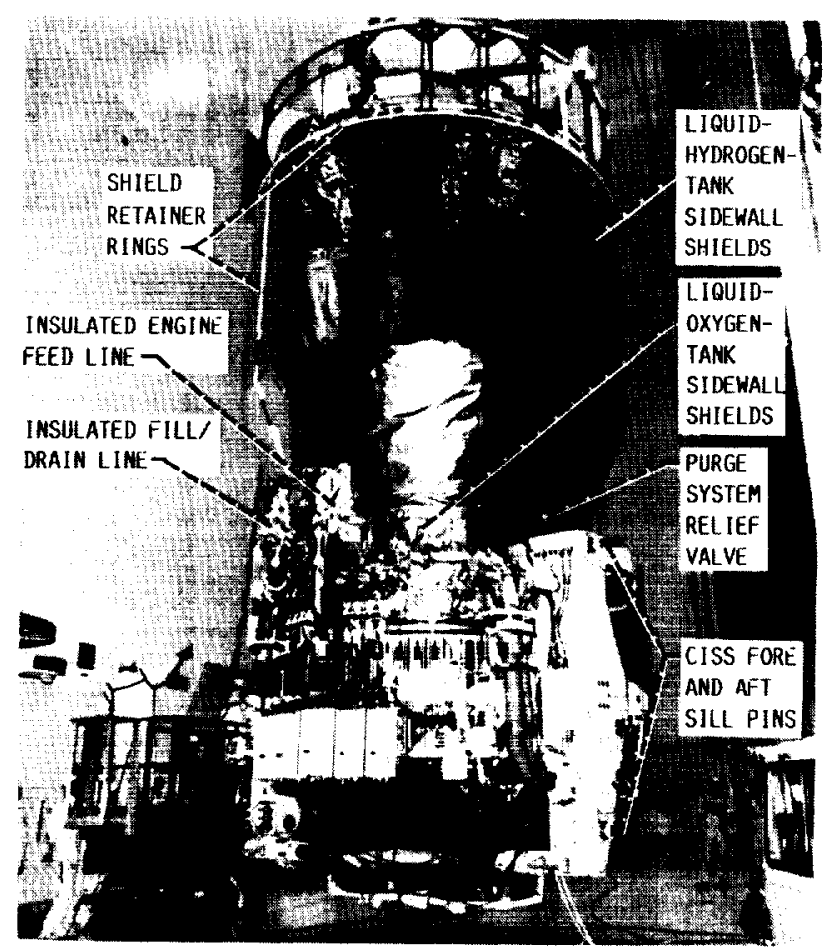

FIGURE 18. - SHUTTLE/CENIAUR G-PRIME MATED TO CISS. 

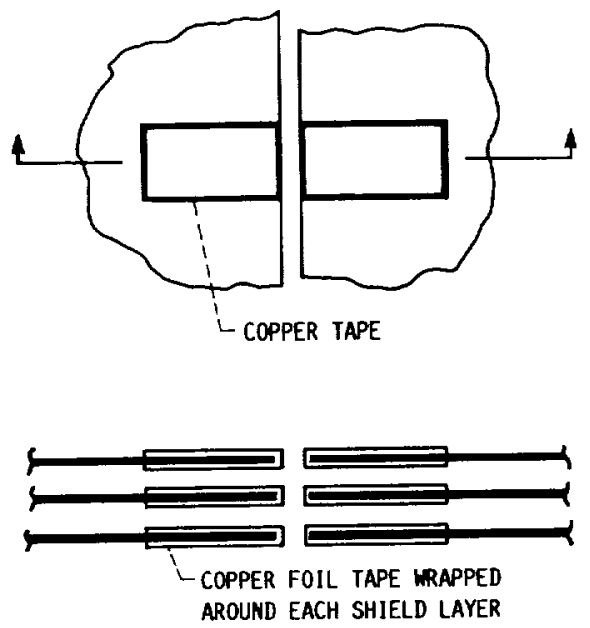

(A) ELECTRICALLY CONDUCTIVE TAPE INTERMITTENTLY APPLIED TO FAYING ALUMINIZED SURFACES BEFORE ASSERBLY

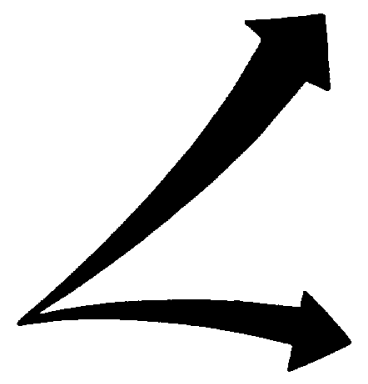

(B) ELECTRICAL BOWDING PROVISIONS BETHEEI SHIELD PANELS ACROSS SEWM JOINTS.

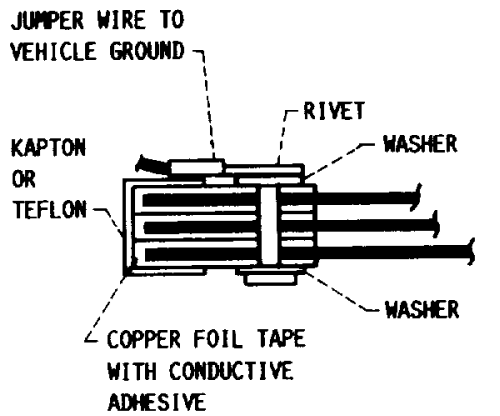

(C) ELECTRICAL BONDING OF SHIELD EDGES TO VEHICLE.

FIGURE 19. - TYPICAL ELECTRICAL BONDING TECHMIQUES FOR RADIATION SHIELDS.

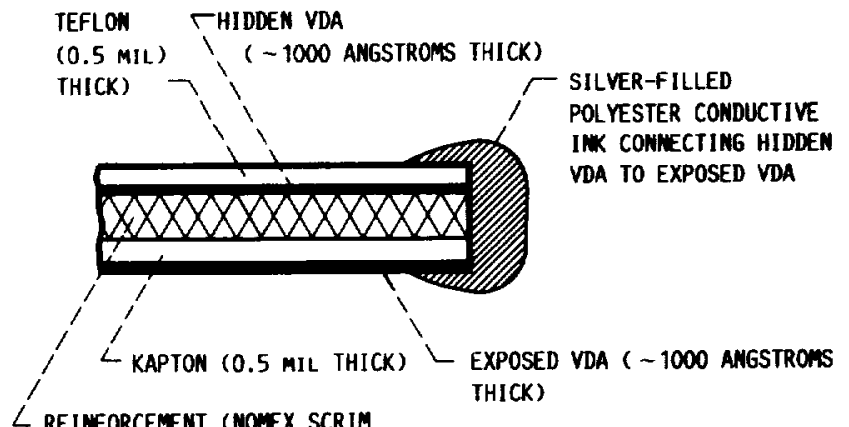

$\angle$ REIHFORCENENT (NOMEX SCRIM

OR KEVLAR (LOTH)

FIGURE 20. - GROUNDING OF HIDDEN VDA ON ALL OUTBOARD SHIELDS OF SHUTTLE/CENTAUR 6-PRIIE.
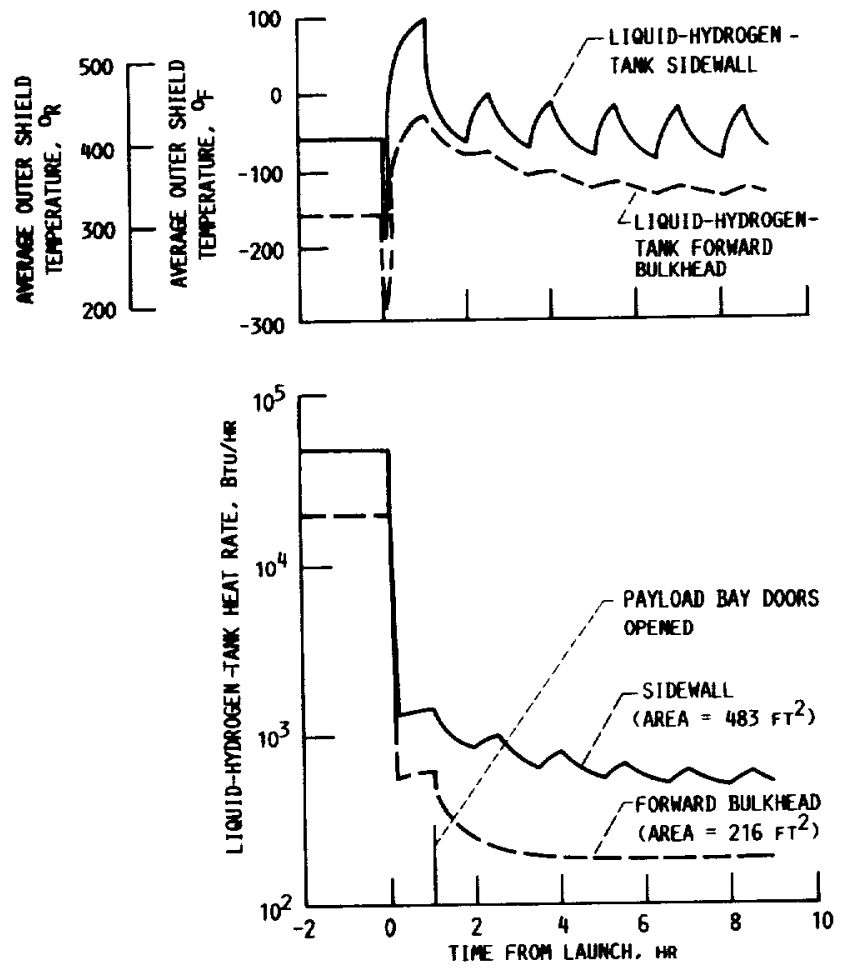

FIGURE 21, - SHUITLE/CENTAUR G-PRINE LIQUID-HYDROGEN-TANK SIDEWALL AMD FORYARD-BULKHEAD TEMPERATURE AND TANK HEATING PREDICTIONS FRON COMPLETION OF LIOUID-HYDROGEM TANMIMG TO STEADY-STATE, ON-ORBIT ( $+X L V, \beta=60^{\circ}$ ) CONDITIOHS. 


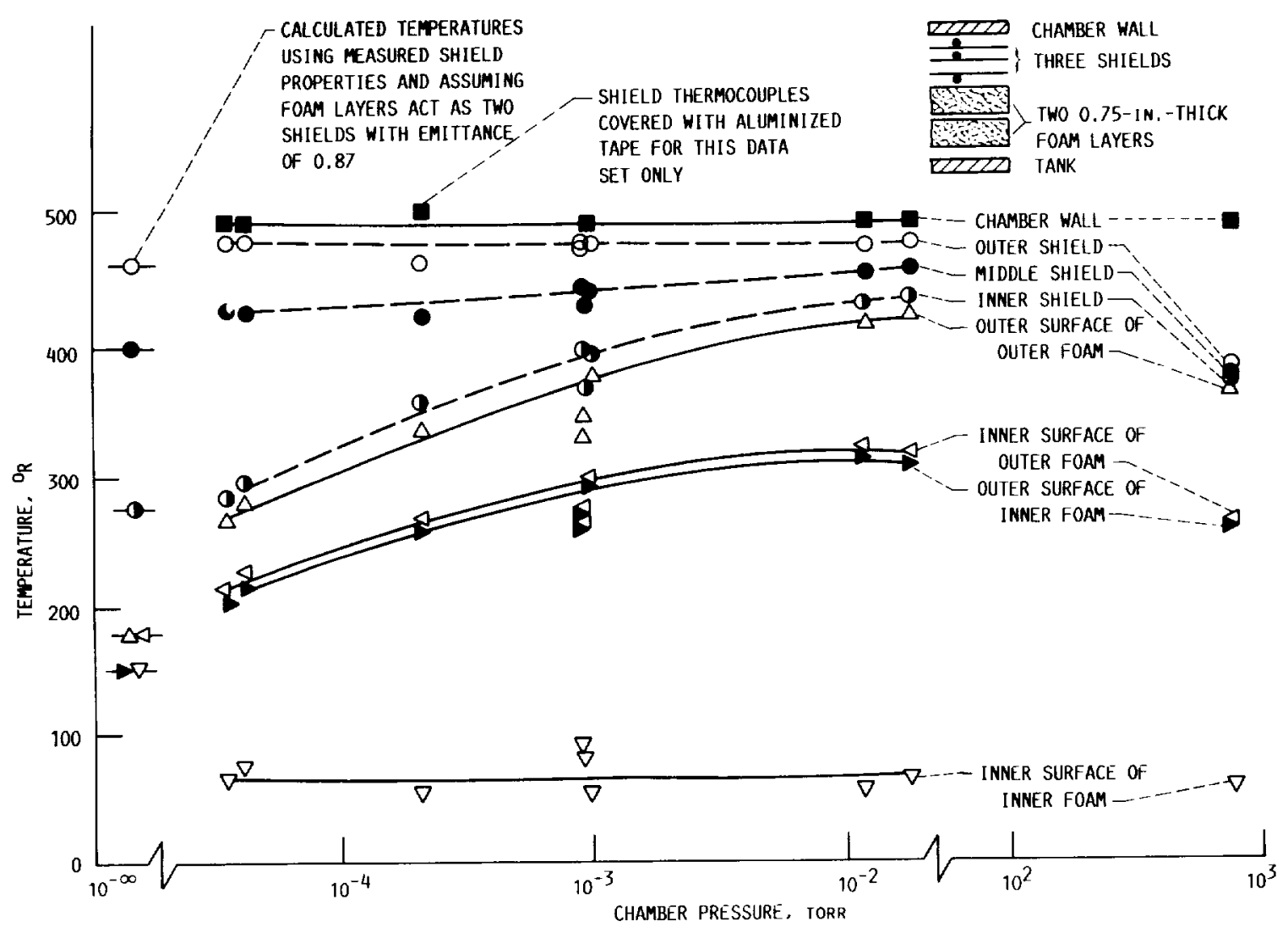

FIGURE 22. - CALORIMETER TESTS ON CENTAUR G-PRIME LIQUID-HYDROGEN-TANK INSULATION SYSTEM (SYSTEM TEMPERATURES).

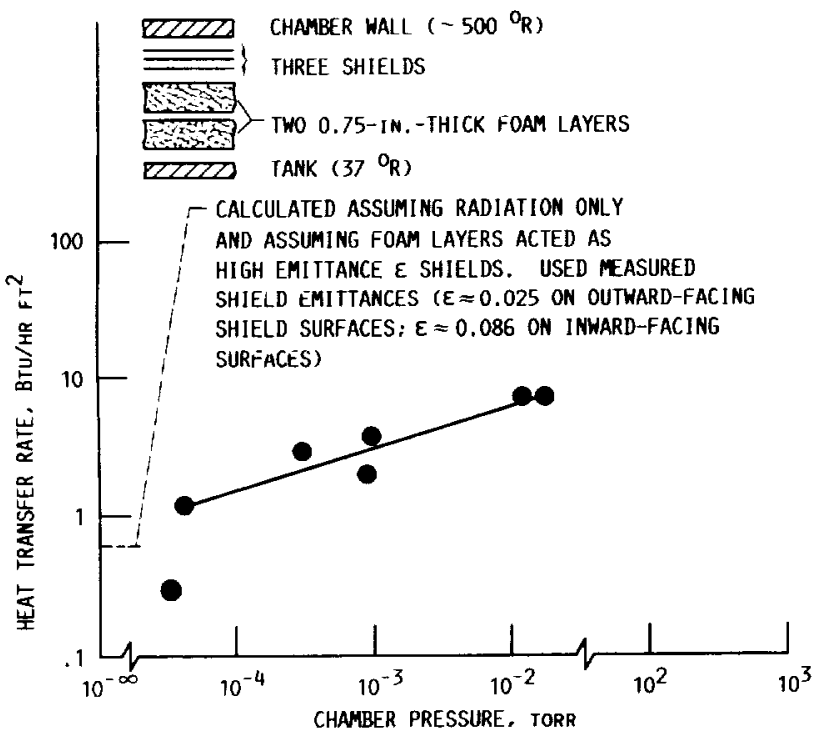

FIGURE 23. - CALORIMETER TESTS ON CENTAUR G-PRIME LIQUIDHYDROGEN-TANK INSULAIION SYSTEM (HEAT TRANSFER).

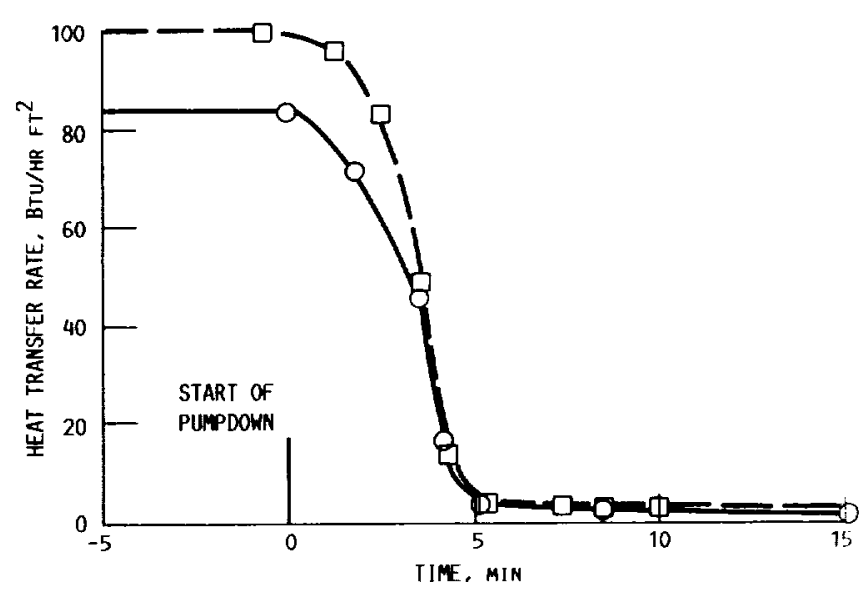

FIGURE 24. - INSULATION SYSTEM HEAT TRANSFER RATES DURING SHUTTLE/CENTAUR G-PRIME ASCENT PRESSURE PROFILE. 


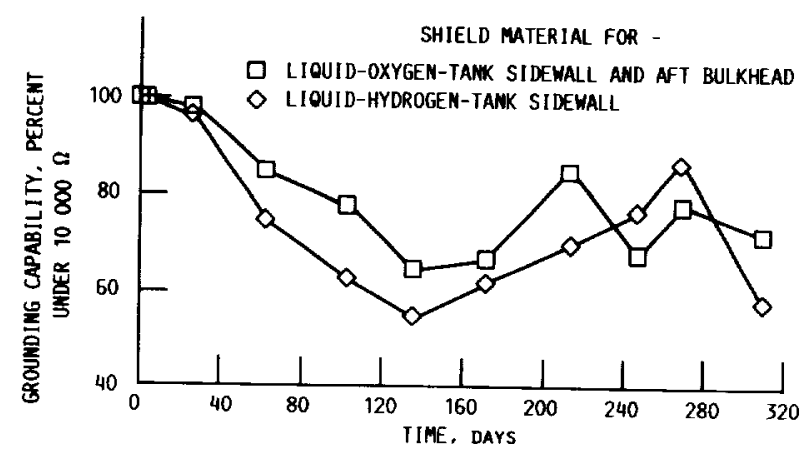

FIGURE 25. - EFFECT OF TIME ON ELECTRICAL GROUNDING OF HIDDEN VDA IN SHUTTLE/CENTAUR G-PRIME OUTERMOST SHIELDS. (SIXTY SAMPLES OF EACH MATERIAL WERE TESTED,)

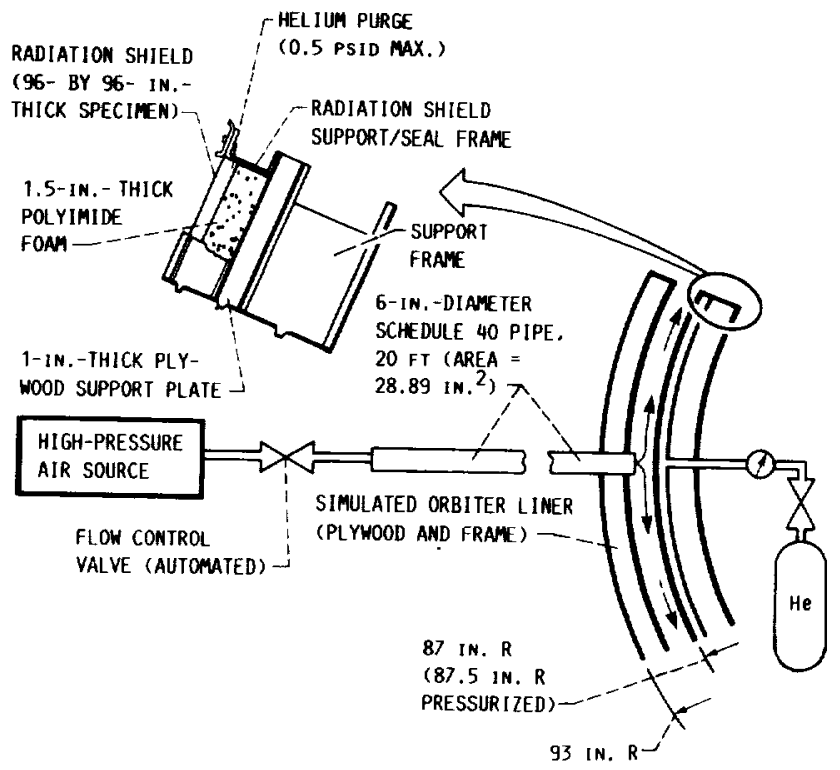

(A) TEST SETUP.

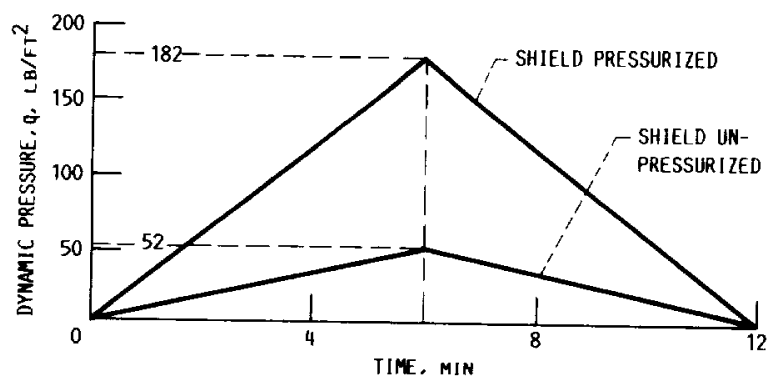

(B) FLOW PROFJLE.

FIGURE 26, - TEST SETUP AND FLOW PROFILE USED TO SIMULATE SHUTTLE CARGO BAY VENT INFLON ON SIDEWALL RADIATION SHIELD. 


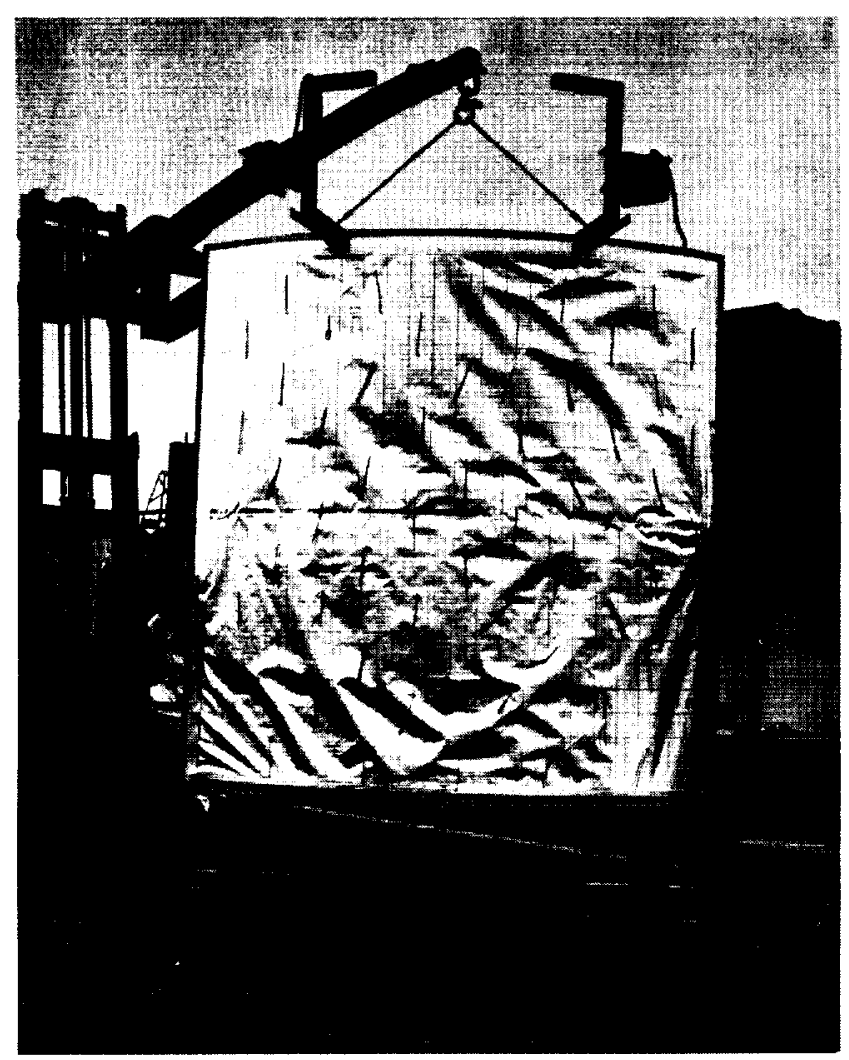

FIGURF 27. SHUTHLF/CENTAUR G-PRIME SIDEWAII. RARIATION SHIELD AFTER EXPOSIIRE IO SIMULATED FLON IMPINGE FENI FROM ORBITER VENTS.

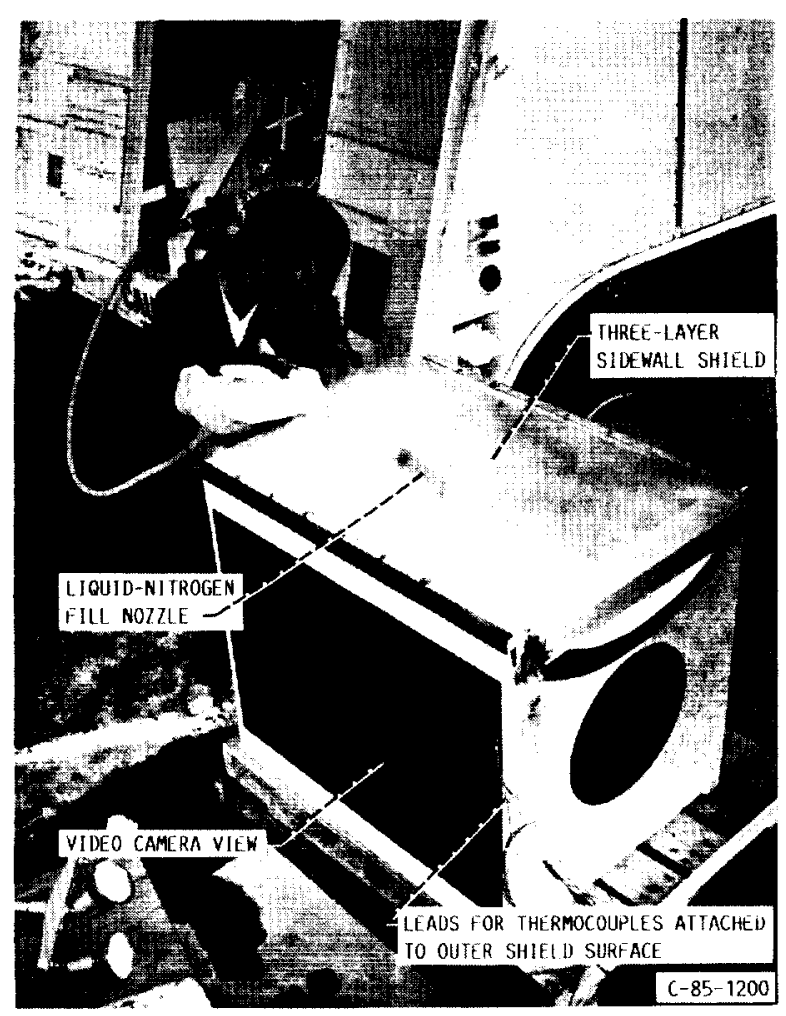

FIGURE 28. - IEST SEIUP FOR DETERMINING IF LIQUID AIR COULD FORM ON EXIERNAL. SURFACES OF SHUTILE/CENIAUR G-PRIME SIDEWALL RADIATION SHIELD.

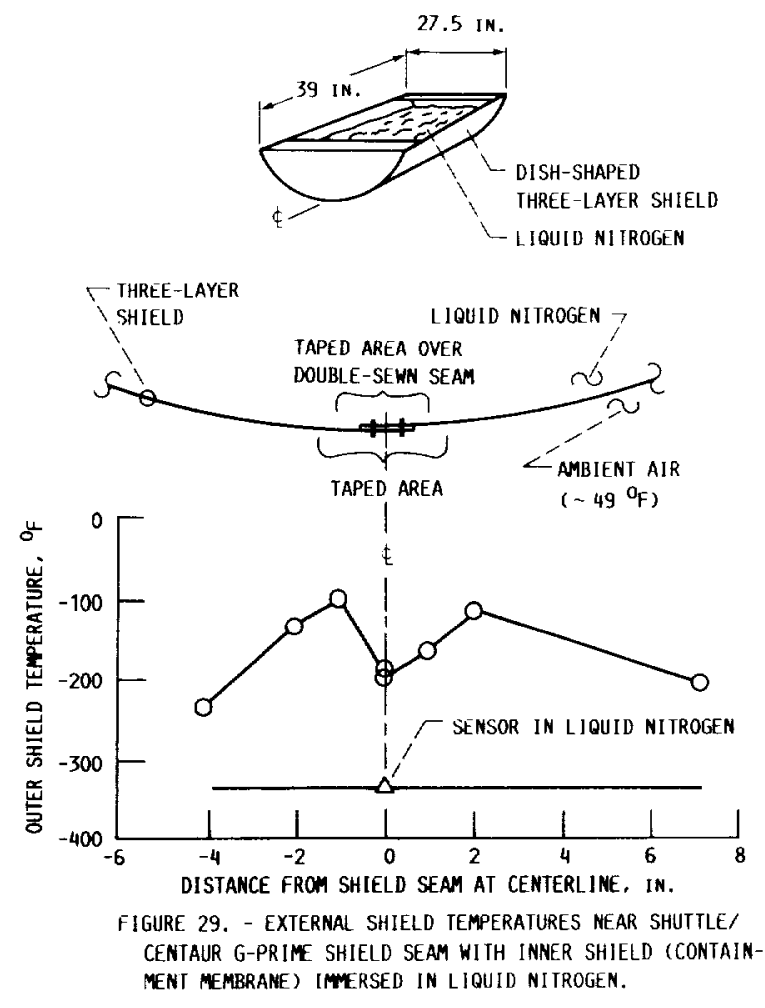




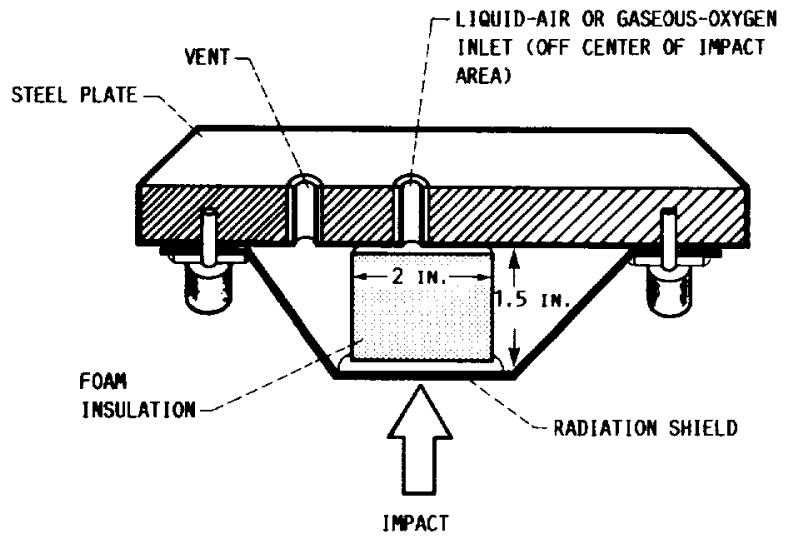

FIGURE 30. - TEST SETUP FOR IMPACTING SHUTTLE/CENTAUR G-PRINE LIQUIDHYDROGEN-TAAK INSULATION SYSTEM WITH LIQUID AIR FORMED INTERMALLY.

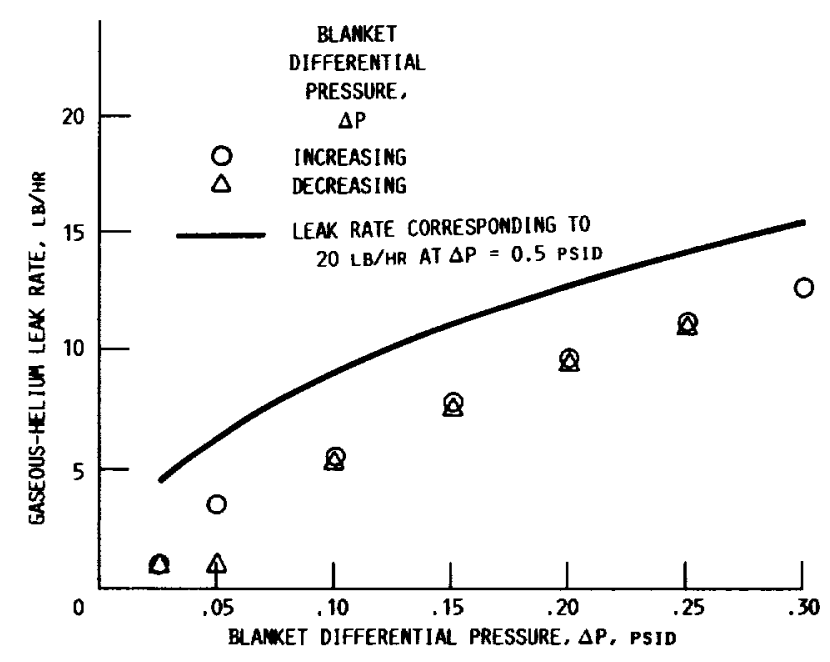

FIGURE 32. - EFFECT OF DIFFEREMTIAL PRESSURE ON LEAK RATE OF SHUTTLE/CEMTAUR G-PRIME LIQUID-HYDROGEN-TAIKK IMSULATIOM BLAMKET.

\section{ORIGINAL PACE IS \\ OF POOR QUALITY}

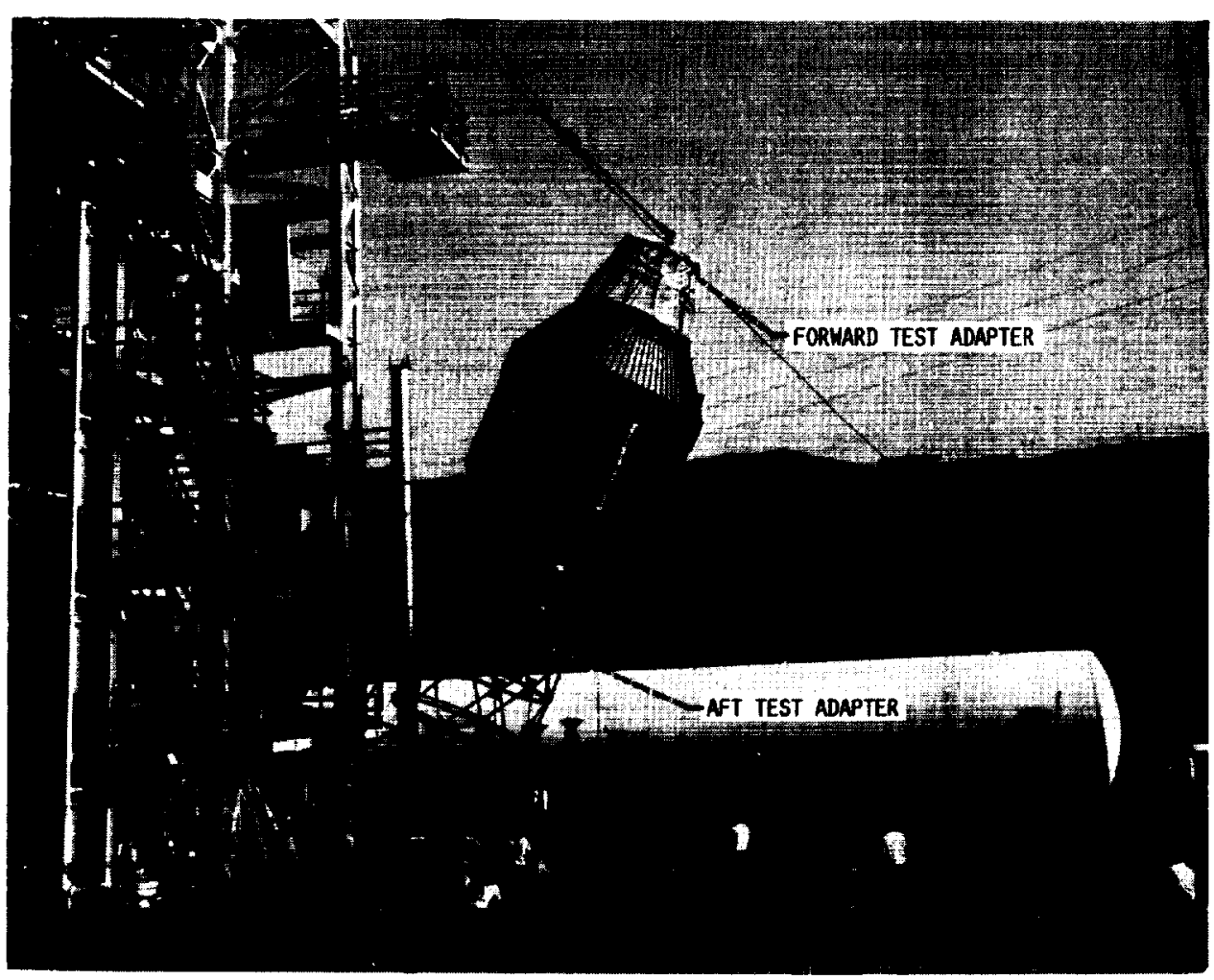

FIGURE 31. - CENTAUR G-PRIME TEST TANK BEIMG INSERTED INTO TEST STAND. 

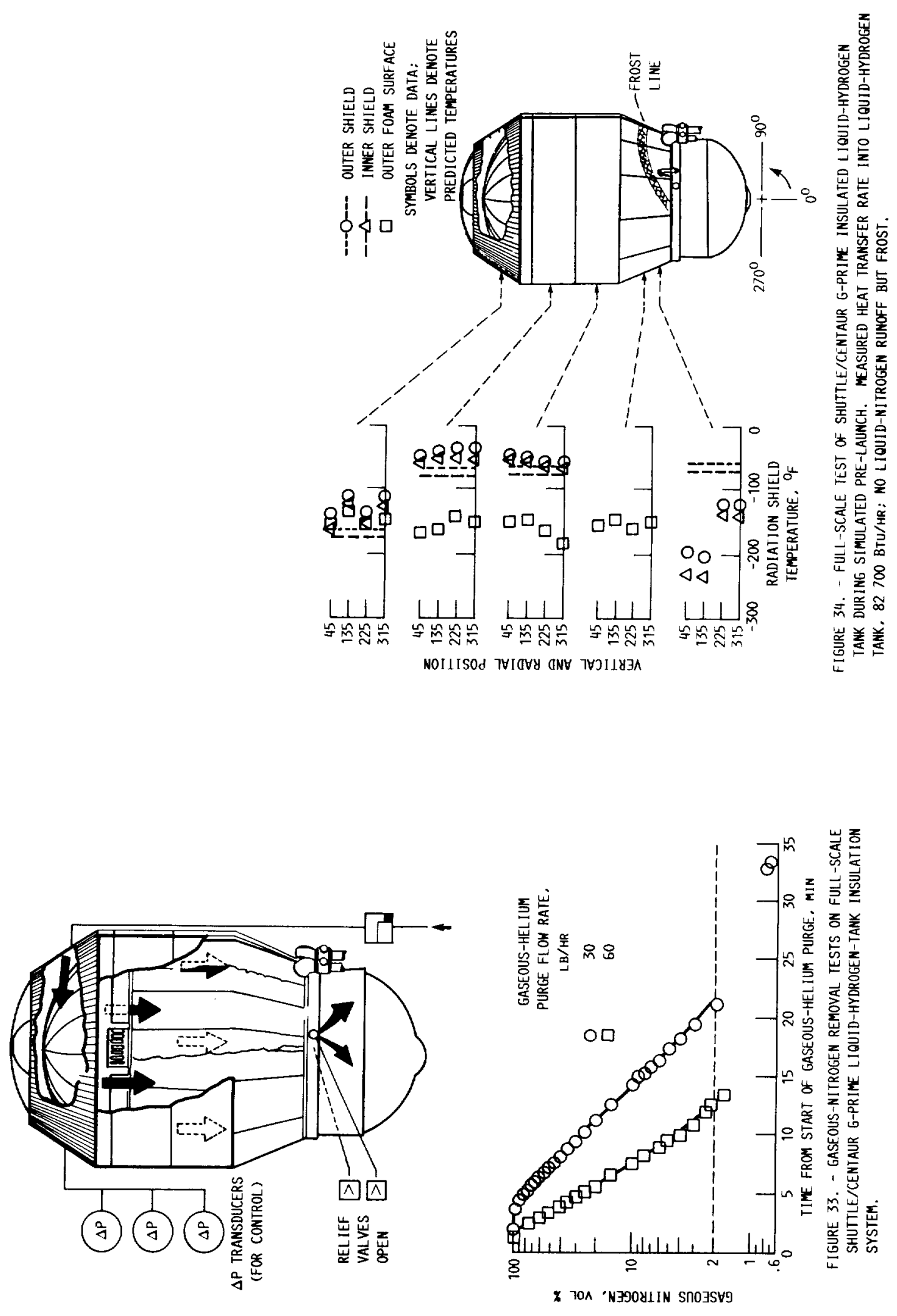


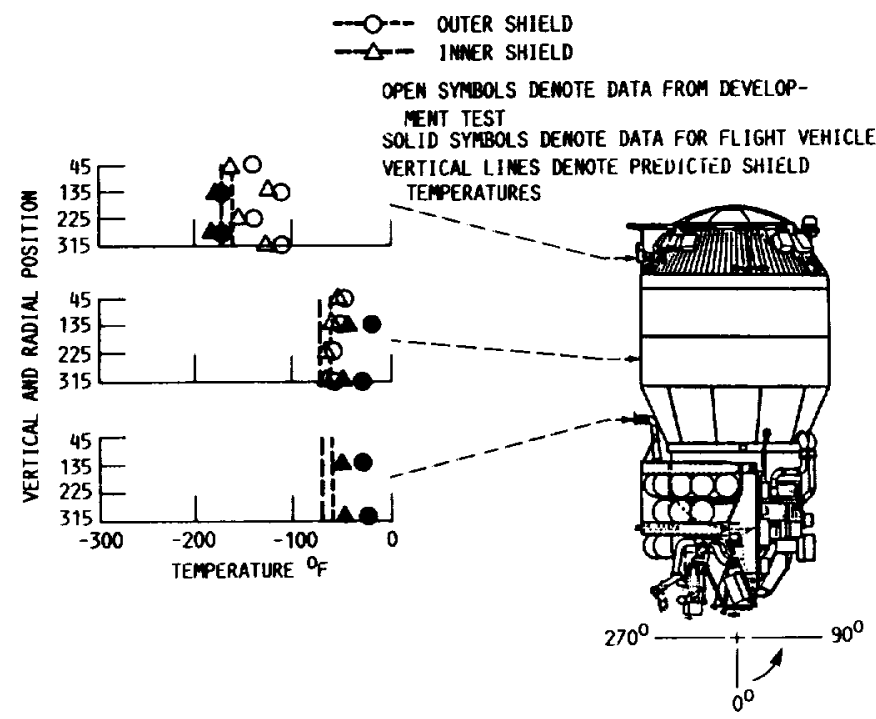

F16URE 35. - THERMAL PERFORMANCE OF THERMAL PROTECTION SYSTEMS FOR SHUTTLE/ CENTAUR G-PRIME FLIGHT VEHICLE 1 CYROGENIC TANKS DURING SIMLLATED PRELAUNCH CONDITIOMS. HEAT TRAFFER RATES. BTU/HR: INTO LIQUID-HYDROGEN TANK, 88 500: INTO LIOUID-OXYGEN TANK, 44000.

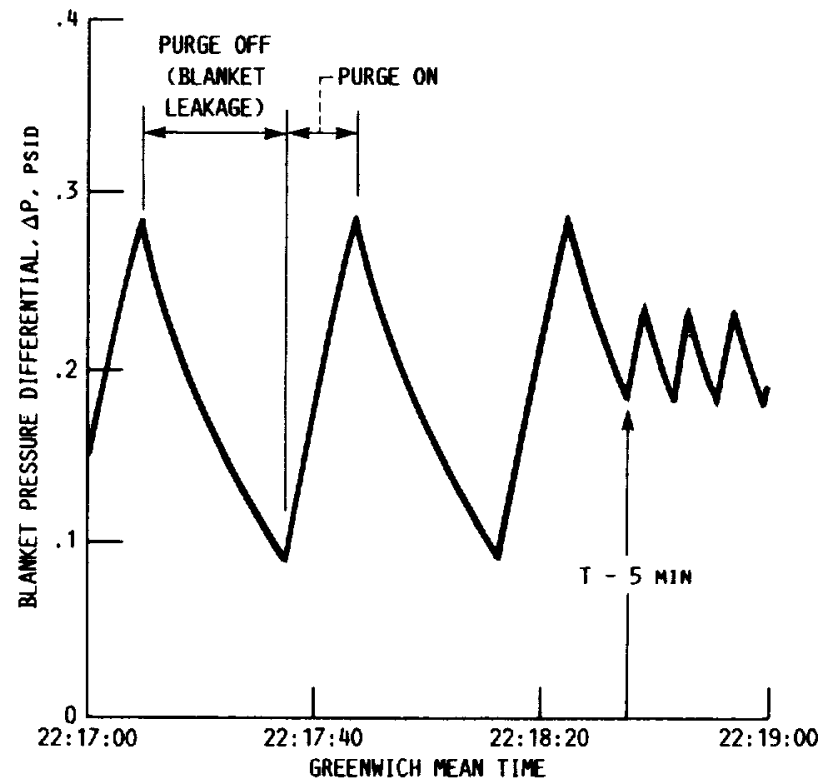

FIGURE 36. - RESETTING OF BLANEET CONTROL BAMD AT 5 MIN BEFORE SIMULATED LAUNCH OF SHUTTLE/CENTAUR 6-PRIME FLIGHT VEHICLE 1 (SECOND TANKING). 


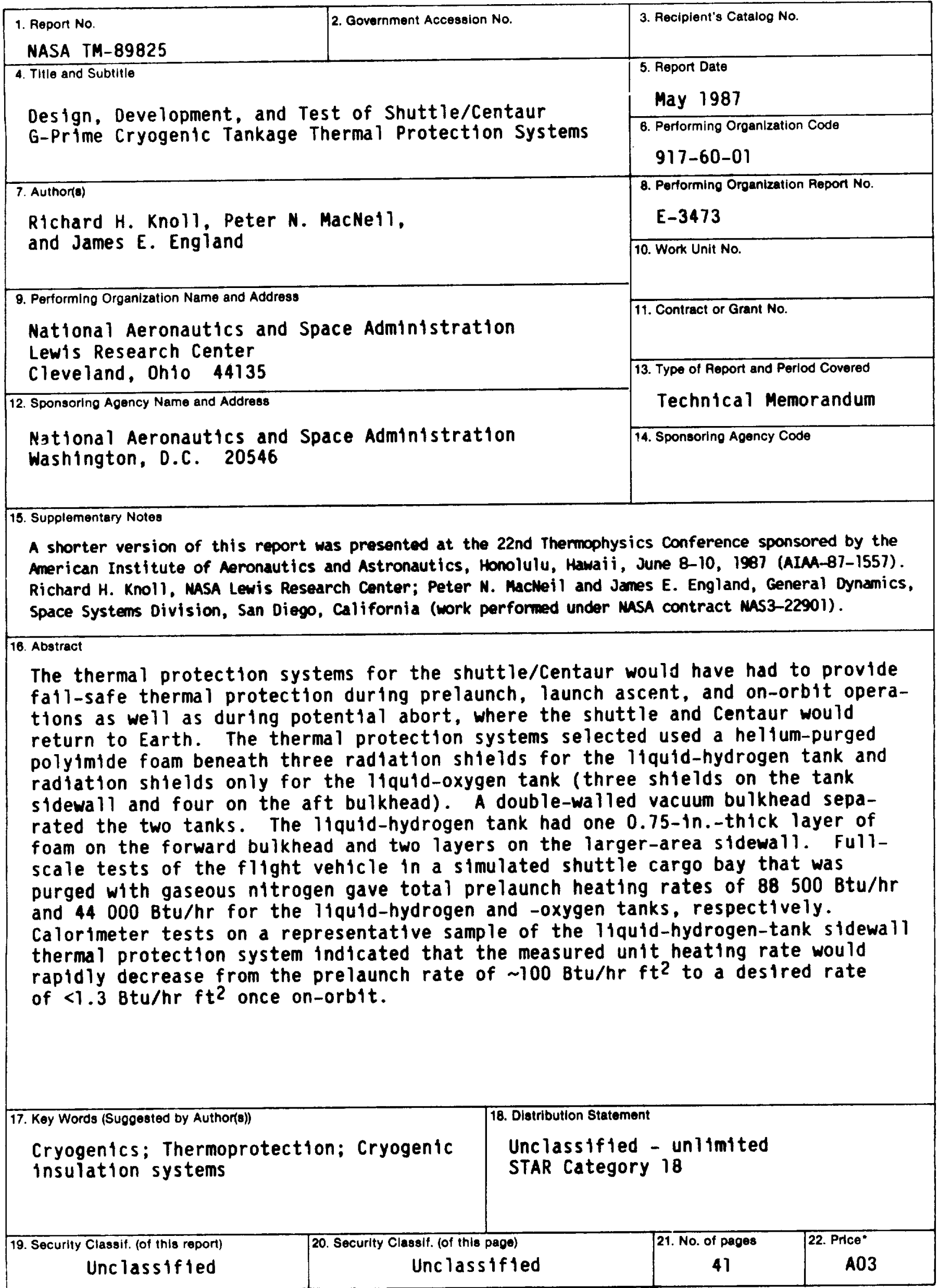

*For sale by the National Technical Information Service, Springfield, Virginia 22161 
